\title{
Nociceptors: a phylogenetic view
}

\author{
Ewan St. John Smith • Gary R. Lewin
}

Received: 3 August 2009 / Revised: 15 September 2009 / Accepted: 20 September 2009 / Published online: 11 October 2009

(C) The Author(s) 2009. This article is published with open access at Springerlink.com

\begin{abstract}
The ability to react to environmental change is crucial for the survival of an organism and an essential prerequisite is the capacity to detect and respond to aversive stimuli. The importance of having an inbuilt "detect and protect" system is illustrated by the fact that most animals have dedicated sensory afferents which respond to noxious stimuli called nociceptors. Should injury occur there is often sensitization, whereby increased nociceptor sensitivity and/or plasticity of nociceptor-related neural circuits acts as a protection mechanism for the afflicted body part. Studying nociception and nociceptors in different model organisms has demonstrated that there are similarities from invertebrates right through to humans. The development of technology to genetically manipulate organisms, especially mice, has led to an understanding of some of the key molecular players in nociceptor function. This review will focus on what is known about nociceptors throughout the Animalia kingdom and what similarities exist across phyla; especially at the molecular level of ion channels.
\end{abstract}

Keywords Nociception - Mechanosensation - Pain · ASIC $\cdot$ TRP

\begin{tabular}{|c|c|}
\hline Abbreviatic & ons \\
\hline ASIC & Acid-sensing ion channel \\
\hline DEG/ENaC & Degenerin/epithelial $\mathrm{Na}^{+}$channel \\
\hline DRG & Dorsal root ganglion \\
\hline IASP & International Association for the Study of Pain \\
\hline LE & Left E cell \\
\hline
\end{tabular}

E. St. J. Smith $(\square) \cdot$ G. R. Lewin Department of Neuroscience, Max-Delbrück Center for Molecular Medicine, Robert-Rössle-Strasse 10,13125 Berlin-Buch, Germany e-mail: ewan.smith@mdc-berlin.de

$\begin{array}{ll}\text { NaV } & \text { Voltage-gated sodium channel } \\ \text { SLP3 } & \text { Stomatin like protein-3 } \\ \text { TRP } & \text { Transient receptor potential } \\ \text { TRPA1 } & \text { Transient receptor potential ankyrin-1 } \\ \text { TRPM8 } & \text { Transient receptor potential melastatin-8 } \\ \text { TRPV1/4 } & \text { Transient receptor potential vanilloid-1/4 } \\ \text { TTX } & \text { Tetrodotoxin } \\ \text { VC } & \text { Ventrocaudal }\end{array}$

\section{Introduction}

About 150 years ago Charles Darwin stated that: "any variation...if it be in any degree profitable to an individual of any species... will tend to the preservation of that individual, and will generally be inherited by its offspring" (Darwin 1859). The ability of an organism to detect and effectively respond to aversive stimuli is certainly a profitable trait that one would expect is not restricted to higher vertebrates. Nociception, derived from the Latin nocere meaning "to hurt/harm", is the name given to the process by which organisms detect potentially or actually damaging stimuli. In humans, the basis of this system is a dedicated class of sensory afferents called nociceptors, defined by the International Association for the Study of Pain (IASP) as, "a receptor preferentially sensitive to a noxious stimulus or to a stimulus which would become noxious if prolonged". It is important to differentiate between nociception and pain because the latter always encompasses an emotional component and the IASP stresses that nociceptor activation is itself not pain. The proposal that there are sensory afferents, which specifically detect noxious stimuli, was first advanced by Charles Sherrington, "there is considerable evidence that the skin is provided with a set of nerve-endings whose specific office it is to be amenable to stimuli that 
do the skin injury...preferably termed nocicipient" (Sherrington 1903). This review will focus on the following: (1) the basic properties of mammalian nociceptors; (2) evidence for nociceptors and their evolution throughout the Animalia kingdom; (3) similarities in the underlying mechanisms used by nociceptors to detect noxious stimuli. Pain in general and central nervous system aspects of pain/nociception are not the subject of this review and have been extensively discussed elsewhere (Millan 1999; Tracey 2005).

\section{What are nociceptors?}

When examining the mammalian nociceptive system it is clear that the IASP definition of a nociceptor given above is oversimplified; there are in fact many types of nociceptors. Our understanding of nociceptor function and nociception has come about through four main experimental methods: electrophysiological examination of the responses of single sensory afferent fibers in teased nerve preparations, wholecell patch clamp analysis of cultured sensory neurons, microneurography in human volunteers and the study of an organism's behavior in response to noxious stimuli. In mammals it is the skin that most often encounters potentially damaging stimuli and, therefore, cutaneous sensory afferents have been extensively examined. This review will, therefore, concentrate on comparative studies where noxious stimuli have been applied externally; studies on nociception from deep tissue or viscera in organisms outside mammalia are in any case very rare.

The early breakthroughs in the study of nociceptors came from the work of Ed Perl and colleagues. They used teased fiber methods to record extracellularly from single $\mathrm{A} \delta$ - and $\mathrm{C}$-fiber afferents in cutaneous nerves of the cat, Felis catus, and clearly demonstrated that there are certain classes of afferents, which only respond to noxious stimuli (Burgess and Perl 1967; Bessou and Perl 1969). Later, Reeh showed that teased fiber recordings can be made in an in vitro skin-nerve preparation (Reeh 1986) and this method has subsequently been successfully adapted to record from cutaneous afferents both in wild type and mutant mice, Mus musculus (Koltzenburg et al. 1997; Caterina et al. 2000; Price et al. 2000; Bautista et al. 2007; Milenkovic et al. 2007; Wetzel et al. 2007; Malin et al. 2008; Kwan et al. 2009). Similar models have also been developed for investigating the properties of visceral afferents (Brierley et al. 2004) and muscle afferents (Wenk and McCleskey 2007). It is also possible to record from single afferent fibers in awake human volunteers through the technique of microneurography, developed by Vallbo and Hagbarth (Vallbo and Hagbarth 1968). This technique has confirmed many of the findings from animal studies, but obviously has the clear advantage of much better communi- cation between experimenter and subject (recently reviewed by Namer and Handwerker 2009).

\section{Cutaneous sensory receptors}

Cutaneous afferents, the cell bodies of which are in the dorsal root ganglia (DRG), can be split into two main groups according to axon caliber and myelination: large diameter, myelinated A-fibers and small diameter, unmyelinated C-fibers. Several C-fiber axons are packed into individual Remak bundles, which are ensheathed by a non-myelinating Schwann cell. As a consequence of axon caliber and myelination status, A-fibers conduct action potentials very much faster than C-fibers (A-fiber conduction velocity $=1.2$ $40 \mathrm{~m} / \mathrm{s}$; C-fiber conduction velocity $=0.3-1.2 \mathrm{~m} / \mathrm{s}$ ).

\section{A-fibers}

$\mathrm{A} \beta$-fibers have a large diameter and a thick myelin sheath. These are very rapidly conducting fibers involved in detecting non-noxious mechanical stimuli (reviewed by Lynn 1994; Lewin and Moshourab 2004). A $\delta$-fibers have a somewhat smaller axon diameter and thinner myelin sheath. These axons are slowly conducting and are classified either as low-threshold, D-hair mechanoreceptors or mechanoreceptors activated by high-intensity, noxious stimuli: A $\delta$-mechanonociceptors (Koltzenburg et al. 1997; Lewin and Moshourab 2004). Whereas A $\beta$-fibers innervate a variety of defined structures in the hairy and glabrous skin of rodents, such as hair follicles and Meissner corpuscles, $\mathrm{A} \delta$-fibers lose their myelin and terminate as free endings in the epidermis (Kruger et al. 1981). Burgess and Perl (1967) were the first to examine $\mathrm{A} \delta$-fibers in any great detail, noting that they "responded only to damaging stimulation of the skin". In the mouse, $\mathrm{A} \delta$-mechanonociceptors have mechanical thresholds that are significantly higher than those for A $\beta$-mechanoreceptors (see Fig. 1; Koltzenburg et al. 1997; Cain et al. 2001). Work in the mouse has shown that some $\mathrm{A} \delta$-mechanonociceptors are thermosensitive, $12 \%$ are heat sensitive (threshold $\sim 42^{\circ} \mathrm{C}$ ) and $50 \%$ are cold sensitive (threshold $\sim 8^{\circ} \mathrm{C}$; Cain et al. 2001). Activation of human $\mathrm{A} \delta$-mechanonociceptors by temperatures above $45^{\circ} \mathrm{C}$ has also been reported (Adriaensen et al. 1980). A $\delta$-mechanonociceptors adapt slowly to a stimulus, which corresponds with the fact that noxious stimuli trigger a painful sensation throughout the duration of the stimulus (Koltzenburg et al. 1997).

\section{C-fibers}

Unmyelinated C-fibers which, like $\mathrm{A} \delta$-mechanonociceptors, terminate in the skin as free endings, are much more abundant than A-fibers (Lewin and Moshourab 2004). Early studies concentrated purely on the mechanoreceptive 


$\begin{array}{llllllll}\text { Fiber Cross section Fiber type } & \text { Sensation } & \%^{a} & \mathrm{CV}(\mathrm{m} / \mathrm{s}) & \begin{array}{l}\mathrm{VFT} \\ (\mathrm{mN})^{b} \text { Sensitivity }\end{array} \\ \end{array}$

Fig. 1 Mammalian cutaneous fiber types. Approximate diameters given are from measurements in the cat, which is best characterized in

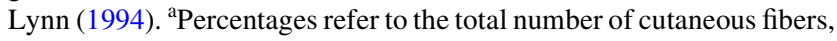
from data in Kress et al. (1992), Cain et al. (2001), Lewin and Moshourab (2004) and Albers et al. (2006); ${ }^{\mathrm{b}}$ Data from Koltzenburg et al. (1997), Cain et al. (2001), Albers et al. (2006) and Martinez-Salgado et al. (2007); 'Some neurons express ion channels, the activation of which produces sensations of warm/cool rather than painfully hot/cold. Depicted is only whether it is possible for a class of neuron to transduce noxious hot (red)/cold (blue), it does not, however, mean that every neuron in that class does. ${ }^{\mathrm{d}}$ Only after sensitization as in Kress et al. (1992); ${ }^{\mathrm{e} B a s e d}$ upon Loken et al. (2009). $n f$ nerve fiber, $m s$ myelin sheath, $C V$ conduction velocity, $v F T$ von Frey threshold, $m N$ milliNewtons, $R A M$ rapidly adapting mechanoreceptor, $S A M$ slowly adapting mechanoreceptor, $A M \mathrm{~A} \delta$-mechanonociceptor, $C M$ C-mechanonociceptor, $C M H$ C-mechanoheatnociceptor, $C M C$ C-mechanocoldnociceptor, $\mathrm{CH}$ C-heatnociceptor and $C L T \mathrm{C}$-low threshold fiber

properties of these fibers (Iggo 1960) and their polymodality was first investigated thoroughly in the cat by Ed Perl and colleagues (Bessou and Perl 1969). C-fibers are generally viewed as responding only to noxious stimuli, but these early studies identified a set of low threshold C-fibers that were activated by innocuous stimuli, $<0.05 \mathrm{~g}$, (Bessou and Perl 1969). In humans, activation of these neurons is proposed to code for pleasant touch rather than nociception (Loken et al. 2009). The remaining C-fiber population is, however, largely polymodal, responding to noxious stimuli of all types: mechanical, heat and chemical (e.g. acid), in a slowly adapting manner (Bessou and Perl 1969). Acid activates nociceptors in many mammalian species, but a unique exception is the African naked mole-rat Heterocephalus glaber, where no primary afferent fibers are activated by acid, corresponding with a lack of nociceptive behavior after acid injection (Park et al. 2008). In the mouse, some studies have found that these $\mathrm{C}$-fibers have much higher mechanical thresholds than $\mathrm{A} \delta$-mechanonociceptors (Cain et al. 2001), whereas others have found that the values are quite similar (Koltzenburg et al. 1997; Milenkovic et al. 2008). An explanation for these differences could be that the nerves recorded from and the skin innervated differed in the studies from different groups (tibial/glabrous vs. saphenous/hairy). The mechanical thresholds in both studies were, however, higher than the thresholds for $\mathrm{A} \beta$-mechanoreceptors and the greatest activation occurred with stimuli that are clearly noxious, thus differentiating nociceptors from mechanoreceptors. The percentage of C-fibers activated by noxious heat varies from study to study but in general $\sim 70 \%$ are heat sensitive with a threshold of $\sim 40^{\circ} \mathrm{C}$ (Cain et al. 2001; Lewin and Moshourab 2004). There is much less agreement about the percentage of polymodal Cfibers that are also sensitive to noxious cold. In one study the majority of heat sensitive fibers were described as being cold sensitive with a threshold of $\sim 10^{\circ} \mathrm{C}$ (Cain et al. 2001). However, other studies have not found such a high proportion of noxious cold sensitive fibers (Lewin and Mendell 1994; Kwan et al. 2009). Although the percentage of C-fibers classified as thermosensitive has been shown to vary between studies, the activation thresholds for noxious heat and cold of $\sim 40^{\circ} \mathrm{C}$ and $\sim 10^{\circ} \mathrm{C}$ correlate well with temperatures identified in humans that cause heat and cold pain, respectively (Treede et al. 1992; Davis and Pope 2002). Not all C-fibers encoding noxious stimuli are polymodal, some are activated purely by noxious mechanical stimuli, others by just heat, some by mechanical and heat and some by mechanical and cold. However, these are fewer compared to polymodal C-fibers (Fig. 1; Koltzenburg et al. 1997; Cain et al. 2001; Lewin and Moshourab 2004). The last group of C-fibers, identified in both rodents and humans is termed "sleeping" or "silent" owing to the fact that these fibers are not activated by mechanical or thermal stimuli (Handwerker et al. 1991; Schmidt et al. 1995; Weidner et al. 1999). However, after incubation with inflammatory mediators some of these insensitive fibers become responsive to mechanical and/or heat stimuli, a process known as sensitization (Meyer et al. 1991; Kress et al. 1992). A summary of mammalian fiber properties is given in Fig. 1.

Ideally, one would want to record activation of nociceptors at the receptor ending, but at the moment, due to the very small size and restricted access to the endings, this has not been feasible. One method that has been used to try and bypass this issue is to examine nociceptor function in vitro using whole-cell patch-clamp of acutely isolated DRG sensory neurons, which are often used as an in vitro model of the sensory afferent ending. In vertebrates, the cell bodies of sensory afferents are located in the DRG and in culture it is possible to examine chemical, thermal and mechanical sensitivity (Baccaglini and Hogan 1983; Cesare and McNaughton 1996; McCarter et al. 1999). Using this method DRG neurons have been classified into different groups allowing for the identification of distinct DRG neurons as nociceptors. A characteristic feature of nociceptors is that they have wide action potentials (mean half-peak duration approximately $3 \mathrm{~ms}$, compared to approximately $1 \mathrm{~ms}$ for pure mechanoreceptors in mouse, see Lechner et al. 2009) with a hump on the repolarization phase (see Fig. 2, 


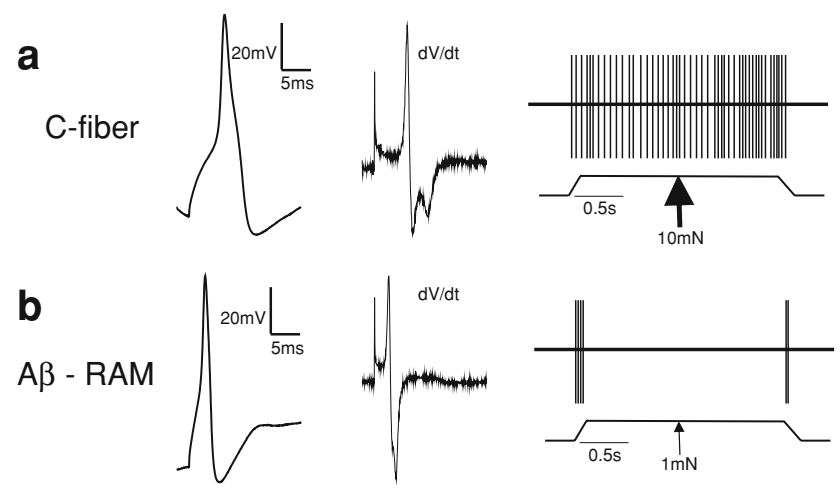

Fig. 2 a Narrow diameter C-fibers have wide action potentials characterized by an inflection on the repolarization phase, as can be seen in the first derivative of the spike (dV/dt), which exhibits two relative minima. Strong mechanical stimulation (thick arrow) produces a slowly adapting response. $\mathbf{b}$ Wide diameter mechanoreceptors have narrow action potentials with only one minimum in the first derivative spike. RAM fibers are activated by low mechanical stimulation (thin arrow) and only respond to the dynamic phase of the stimulus. The example AP traces/derivatives are recordings from mouse DRG neurons and the diagrams on the right-hand side are representative of action potential firing in murine $\mathrm{C}$ - and $\mathrm{A} \beta$-fibers upon stimulation

Koerber et al. 1988; reviewed in Lawson 2002). In mice DRG neurons with humped action potentials can already be observed from embryonic day 13.5 (Lechner et al. 2009), coinciding with the wave of neurogenesis in which nociceptors are born (Ma et al. 1999). The culturing of DRG neurons also allows for nociceptors to be easily split into different groups depending upon their sensitivity to different natural stimuli, which is presumably largely determined by the range of transduction molecules that they express (for more information see Woolf and Ma 2007).

\section{Sensitization}

Interestingly, nociceptors do not have fixed properties, but instead display great plasticity as evidenced by a process called sensitization. This phenomenon manifests as either non-responsive neurons becoming responsive, or neurons responding at reduced threshold and/or producing responses of greater magnitude. As a result, pathways that are involved in nociceptive signaling are activated more extensively and/or strongly. Such sensitization can be evoked by repeated stimulation. For example, repetitive application of a heat ramp to polymodal C-fibers leads to action potentials being initiated at ever lower temperatures (Bessou and Perl 1969). However, sensitization occurs most commonly in response to inflammation and is a protective mechanism, whereby increased sensitivity of nociceptors causes the injured body part to be protected, thus preventing further damage (Lewin et al. 2004; Woolf and Ma 2007). During inflammation mast cells degranulate, inflammatory cells release their contents and cells are broken down, resulting in nociceptors being immersed in a pool of molecules, sometimes referred to as an "inflammatory soup", including: protons, prostanoids, growth factors, nitric oxide, arachidonic acid, kinins, cytokines, and ATP. These substances modulate ion channels involved both in the detection of noxious stimuli and in subsequent initiation/propagation of action potentials. This occurs either by a direct action on channels or by the activation of intracellular signaling cascades that in turn modulate ion channels (Cesare and McNaughton 1996; Gold et al. 1996; Shu and Mendell 1999; Cadiou et al. 2007; Smith et al. 2007a; Binshtok et al. 2008; Momin et al. 2008; Lechner and Lewin 2009). For example, the transient receptor potential 1 (TRPV1), which is activated by heat, acid and the substance that makes chili taste hot, capsaicin, can be sensitized by several mediators, some of which cause TRPV1 phosphorylation and subsequent insertion of new channels into the membrane (Huang et al. 2006b). The biological benefit of the sensitization process suggests that, as for nociceptors themselves, it is unlikely to be restricted to higher vertebrates.

\section{The emergence of nociceptors in the evolution of the nervous system}

A diverse array of stimuli can be considered as noxious and three main groups will be discussed: mechanical, thermal and chemical. The ability to sense life threatening mechanical forces is perhaps the most conserved sensory trait among living organisms, demonstrated by Escherichia coli bacteria possessing mechanosensitive channels (MscL and MscS, mechanosensitive channel of large or small unitary conductance) that open to release solutes upon an osmotic down-shock to prevent lysis (Sukharev et al. 1994; Levina et al. 1999). However, E. coli are unicellular and so their ability to react to osmotic shock does not constitute a nociceptive response due to the lack of neuronal cells dedicated to the purpose of detecting noxious stimuli. It is generally accepted that the nervous system originated during the early evolution of Eumetazoa (animals with tissues); more simple Parazoa, such as Porifera (sponges) lack a nervous system (Cavelier-Smith et al. 1996). However, genes associated with neuronal development have been identified in Porifera and globular cells in Amphimedon queenslandica may represent a "proto-neural" cell (Richards et al. 2008). Like Porifera, Placozoa also lack a nervous system, however, recent data suggests that Placozoa are actually eumetazoans and that their nervous system has degenerated (Cavelier-Smith et al. 1996; Srivastava et al. 2008), perhaps explaining the presence of some genes associated with neuronal development (Hadrys et al. 2005). It is within the aquatic phyla Cnidaria and Ctenophora that a basic nervous system can be identified and the monophyletic origin of the 
nervous system is thought to have occurred in their immediate common ancestor (Cavelier-Smith et al. 1996). Therefore, it is from this evolutionary time point that one can begin to look for evidence of nociceptors.

The Cnidarian nervous system has the form of a diffuse nerve net with sensory neuron agglomerations at key structures and is seen as the forerunner to more complex nervous systems (Grimmelikhuijzen and Westfall 1995). The Anthoza class of Cnidaria includes sea anemones, such as Calliactis parasitica. Column stimulation produces nervous impulses and strong stimulation, possibly mimicking the gross contact in nature of a foreign body with the column, leads to the closure reflex, which might be viewed as a nociceptive response. No such effect is seen with thermal stimulation, even when strong enough to burn the ectoderm, thus suggesting a lack of thermal sensitivity (Passano and Pantin 1955). Certain Calliactis species form a symbiotic relationship with some hermit crabs and to obtain an anemone some crabs actively tap the anemone causing it to detach and thus allowing it to be taken from a substrate or "stolen" from another crab (Ross 1968). This tappinginduced detachment behavior that can be mimicked by experimental mechanical or electrical stimulation (Ross 1968), which has been argued to be aversive (Kavaliers 1988), and, thus, perhaps a nociceptive response, although there is no direct evidence for this.

\section{Bilateria and the evolution of true nociceptors}

Unlike the radial symmetry displayed by Porifera, Placozoa, Ctenophora and Cnidaria, all other Animalia (apart from adult Echinodermata) display bilateral symmetry and it is within bilaterates that a single major integrative area of the nervous system can be first recognized (Bullock and Horridge 1965). Although all bilaterates are triploblastic, allowing for the development of true organs, some basic bilaterates, such as Platyhelminthes (flatworms) are acoelomates, meaning that they lack an epithelial-lined fluid-filled cavity (coelom). Within the Polycladia order of flatworms Notoplana aticola displays a locomotory escape behavior following pin prick to the worm's posterior end (Koopowitz 1973). Unsurprisingly, decerebration resulted in no locomotive response to mechanical stimulation. However, a longitudinal incision, through the animal's body, made behind the brain and continued posteriorly along the midline for most of the animal's length (thus producing a L-shaped cut through the worm's body), did not prevent locomotory escape behavior, suggesting the presence of a diffuse sensory neural network (Koopowitz 1973). Presumably pin prick represents a noxious stimulus and thus the evoked behavior could be considered as nocifensive. However, the neurons responding to the mechanical stimulus have not yet been examined in detail and, therefore, it is difficult to classify the behavior as being a response to nociceptor stimulation, as opposed to stimulation of neurons responsible for a plethora of sensory functions.

\section{Annelida}

In contrast to $N$. aticola, the identification of neurons, which function as nociceptors, can be easily recognized when examining the nervous system of more complex, coelomate invertebrates. Among invertebrates the Cephalopoda have perhaps the most complex nervous system, but to date no published articles are known to us about nociception. Although the Annelida have a more basic nervous system than the Cephalopoda, the first invertebrate in which a nociceptive cell was identified is in this phylum: the medicinal leech Hirudo medicinalis. Characteristic of Annelida, $H$. medicinalis has a segmented body, each segment possessing a ganglion containing the $\mathrm{T}$ (touch), $\mathrm{P}$ (pressure) and $\mathrm{N}$ (noxious) cells, which send axons into the periphery (Nicholls and Baylor 1968). These cells can be identified visually and have distinct action potential waveforms. $\mathrm{T}$-cells fire in bursts and have narrower action potentials than P- or N-cells, similar to mammalian mechanoreceptors (Koerber et al. 1988) and N-cells have much larger undershoots than P- or T-cells, with a hump sometimes being observed on the falling phase of N-cells (Nicholls and Baylor 1968; Schlue 1976) similar to mammalian nociceptors (Koerber et al. 1988). Like mammalian mechanoreceptors, T-cells have low mechanical thresholds and rapidly adapt, whereas $\mathrm{N}$-cells are slowly adapting and require much greater stimulation, producing the greatest discharge upon pin-penetration of the skin (as seen in Fig. 3; Nicholls and Baylor 1968). The conclusion was that the N-cells are dedicated nociceptors and more recent work has confirmed this finding. Using von Frey hair stimulation the minimum threshold for activation of N-cells was $9.6 \mathrm{mN}$, whereas $\mathrm{P}$ - and T-cells could be activated at $<0.8 \mathrm{mN}$ and $<0.2 \mathrm{mN}$, respectively, confirming the requirement of noxious stimulation for N-cell activity (Pastor et al. 1996). Similar results have been obtained in the horse leech Haemopis sanguisuga (Weston et al. 1984). Using a battery of chemical stimuli it was further shown that some $\mathrm{N}$-cells responded to acid, capsaicin and heat and the results generated some interesting findings regarding the molecules involved in the transduction of noxious stimuli. However, the level of acidity required to produce significant activity in $\mathrm{N}$-cells was $\mathrm{pH} \sim 3.5$, far lower than that known to either induce pain in humans ( $\mathrm{pH}<7.0$; Ugawa et al. 2002), or to activate those ion channels proposed to mediated acid pain: acid sensing 

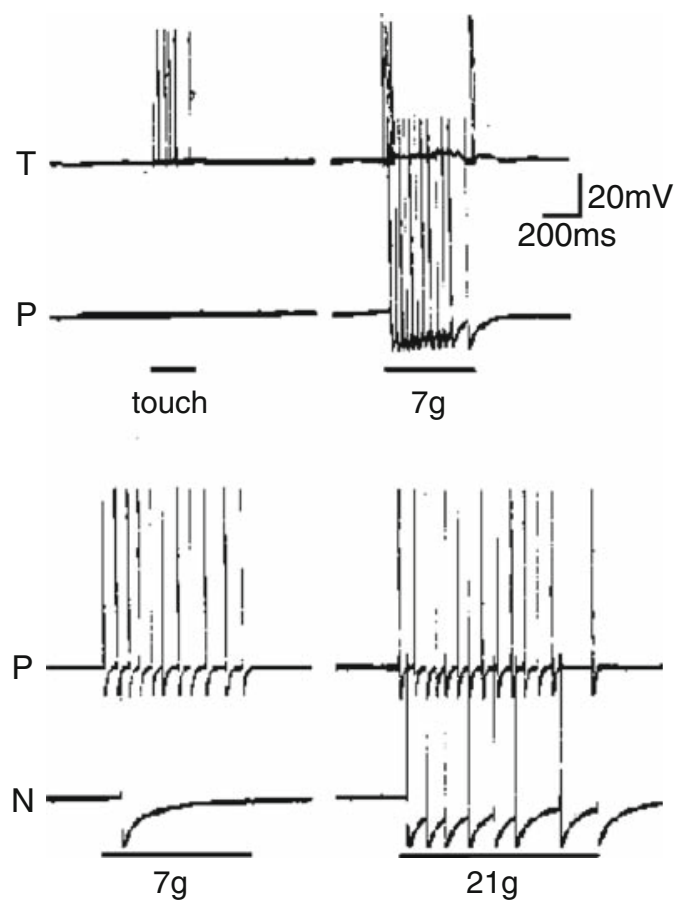

Fig. 3 Intracellular recordings from $\mathrm{T}-, \mathrm{P}_{-}$and $\mathrm{N}$-cells in $H$. medicinalis demonstrating the increased force required to activate $\mathrm{N}$-cells and the tonic firing induced by stimulation (used and modified with permission from Nicholls and Baylor 1968)

ion channels, ASICs and TRPV1. A pH of ca. 7.0 activates ASIC1a and ASIC3 (Hesselager et al. 2004) and $\mathrm{pH} \sim 6.0$ activates TRPV1 (Tominaga et al. 1998). Therefore, the mechanism by which $\mathrm{N}$-cells are activated by acid remains unclear. Capsaicin activates TRPV1, which induces a burning pain in humans and acts as an irritant to rodents. A notable exception is that of the naked mole-rat, $H$. glaber (Park et al. 2008). Similar to acid, very high capsaicin concentrations were required to activate N-cells, $\mathrm{EC}_{50}=240 \mu \mathrm{M}$, far above the $\mathrm{EC}_{50}$ of capsaicin acting on most mammalian TRPV1s, such as $0.71 \mu \mathrm{M}$ for rat, Rattus norvegicus TRPV1 (Caterina et al. 1997) the only known target of capsaicin (Caterina et al. 2000; Davis et al. 2000). Therefore, assuming that $H$. medicinalis expresses TRPV1, it could be that, similar to the chicken, Gallus gallus, (Jordt and Julius 2002) and rabbit, Oryctolagus cuniculus, (Gavva et al. 2004) the TRPV1 expressed by H. medicinalis is less sensitive to capsaicin. Thermal stimuli also activate $\mathrm{N}$-cells with a threshold of $\sim 39^{\circ} \mathrm{C}$, similar to the $\sim 40^{\circ} \mathrm{C}$ heat activation threshold of thermonociceptors in mice (Pastor et al. 1996; Cain et al. 2001). The threshold is not the only similarity of $\mathrm{N}$-cells to mammalian nociceptors; the ability of repeated heat stimulation to lower the threshold for heat-induced nociceptor activation (Bessou and Perl 1969), has also been shown for N-cells (Pastor et al. 1996).
Mollusca

Nociceptors and nociceptive behavior have also been investigated in several species of Mollusca. For example, the land snail, Cepaea nemoralis, responds to placement on a hotplate $\left(\sim 40^{\circ} \mathrm{C}\right)$ with stereotypical lifting of the anterior portion of the extended foot. The expression of opioid receptors and endogenous ligands for these receptors is considered fundamental in determining whether or not nociception can occur (Sneddon 2004). Therefore, it is interesting to note that opiate agonists increased withdrawal latency, which could be blocked by the opiate receptor antagonist, naloxone (Kavaliers et al. 1983). The use of $\delta_{1}$ and $\delta_{2}$ opioid receptor agonists also increased response latency (Thomas et al. 1997) and immunohistochemical staining indicates the presence of endogenous $\delta$-receptor agonists (Sakharov et al. 1993). The hot-plate test is a standard model for measuring nociception in rodents and opiates generally increase the withdrawal latency although strain differences in basal withdrawal latency and the magnitude of the effect of morphine do occur (Mogil et al. 1996). Thus, the action of opioid receptor agonists/antagonists upon withdrawal latency supports the hypothesis that the foot lifting response in C. nemoralis is indeed a nocifensive behavior.

One of the most intensively studied Mollusca is the gastropod, Aplysia californica. The first potentially nociceptive sensory neurons in A. californica, innervating the siphon and mantle, were identified within the left E (LE) cluster of the abdominal ganglion (Castellucci et al. 1970). Initial studies indicated that these were low threshold mechanoreceptors (Byrne et al. 1974), but this was later shown to be due to sensitization induced by tightly pinning out the siphon (Illich and Walters 1997). In a "free siphon" model low-level tactile stimuli that evoked siphon withdrawal failed to activate LE cells. However, upon reaching activation threshold LE-cell activity increased with stimulus strength and maximal activity occurred when crushing/ tearing stimuli, causing body wall damage, were used. These are characteristics of nociceptors, cells tuned to detect noxious stimuli. A second group of sensory neurons are the ventrocaudal (VC) cells of the pleural ganglia. Tactile pressure to the organism's posterior generates graded responses in these cells, which adapt slowly to maintained stimulation. Although responsive to weak stimuli, VC-cells respond most vigorously to pinching of the posterior, which simultaneously evokes "tail" withdrawal, suggestive that pinching is noxious and, therefore, that VC-cells are acting as nociceptors. Indeed electrical activation of a $\mathrm{VC}$ sensory neuron induced motor neuron activation and withdrawal of the "tail", or more correctly the posterior, supporting this theory (Walters et al. 1983). This ability of VC-cells to respond to weak stimulation and most vigorously to 
noxious stimulation is similar to that of a set of mammalian spinal neurons involved in pain transduction called wide dynamic range neurons (Mendell 1966). VC-cells appear to be purely mechanonociceptors as neither $\mathrm{NaCl}$ crystals (which evoke "tail" withdrawal) nor heat cause either LEor VC-cell activation (Walters et al. 1983; Walters 1996). The characteristic phenomenon of nociceptor sensitization has also been demonstrated in Aplysia, whereby after pinching the siphon the mechanical threshold of LE-cells decreased and excitability increased (Illich and Walters 1997). Much is known about the inflammatory mediators inducing mammalian nociceptor sensitization and there appears to be some similarities with sensitization mechanisms in Aplysia such as the ability of serotonin to sensitize both mammalian and Aplysia sensory neurons (Billy and Walters 1989; Woolf and Walters 1991).

A third mollusc, the sea-slug Tritonia diomedia, also possesses a group of cells, situated in the pleural ganglia and identified as sensory in nature: S-cells. These cells respond to mechanical stimulation, but they show rapid adaptation, which is not characteristic of nociceptors (Getting 1976). However, substances deemed noxious due to their evocation of escape swimming (e.g. $\mathrm{NaCl}$ crystals) produced tonic firing in S-cells suggesting a nociceptive function. Indeed, escape swimming is initiated in T. diomedia by electrical activation of S-cells, which supports the idea of them being involved in the triggering of nociceptive responses.

\section{Nematoda}

Although electrophysiological recordings from $H$. medicinalis and A. californica have provided much insight into invertebrate nociception, it is a phylogenetically distant relative that has provided the most information about actual molecules that could be involved in nociceptor transduction mechanism: the nematode worm Caenorhabditis elegans. The nervous system of $C$. elegans is invariant in terms of neuronal position, number and morphology of neurons and thus genetic screens have identified many genes that are involved in specifying neuronal fate and those that underlie a range of physiological processes (Hobert 2005; Schafer 2005; Barr and Garcia 2006; Goodman 2006). Many different types of sensory neurons have been described in C. elegans using physiological methods as well as genetic tools. The ASH pair of neurons have ciliated sensory endings in the worm's anterior end (or "nose", the amphid neurons) and laser removal of these neurons significantly lowers the avoidance response to stimulation of the worm's anterior, a so-called "nose touch" withdrawal, whereas animals lacking all other amphid neurons except for ASH display normal avoidance behavior (Kaplan and Horvitz 1993). Two other neurons,
FLP and OLQ, also play a minor role in this avoidance behavior. There is also strong evidence that the ASH neuron is involved in avoidance behavior to highly osmotic solution, octanol and acid (Troemel et al. 1995; Sambongi et al. 2000; Hilliard et al. 2002) and it has been suggested that the ASH neuron acts like polymodal nociceptors in mammals (reviewed in Tobin and Bargmann 2004). The role of the ASH neuron is not unique to C.elegans, as recent analysis of avoidance behavior in 5 other species of nematode worm has shown that the role of ASH is largely conserved (Srinivasan et al. 2008). Exceptions included the additional requirement of ADL neurons for full high osmotic solution avoidance behavior in Pristionchus pacificus and differences in basal stimulus sensitivity thought to be due to adaptation of species to their respective niches (Srinivasan et al. 2008). A thermal avoidance behavior has also been observed in C. elegans where upon exposure to $\sim 33^{\circ} \mathrm{C}$ a reflex escape response is evoked (Wittenburg and Baumeister 1999). Although it is known that neurons controlling thermotaxis are not involved in the avoidance response, the nociceptive neurons that detect noxious heat in C. elegans are still unknown. Interestingly, capsaicin was seen to sensitize the heat response, but evoked no acute behavior. In conclusion, it appears that $C$. elegans and other nematodes possess neurons, which specifically react to noxious stimuli, the ASH neuron being the best characterized so far.

\section{Arthropoda}

The last invertebrate that will be discussed in detail is the arthropod Drosophila melanogaster which, like C. elegans, is an organism that lends itself to genetic analysis. D. melanogaster undergo a 4-day larval stage and touching larvae with a probe causes them to pause and move away from the stimulus. However, a heated probe $\left(\sim 42^{\circ} \mathrm{C}\right)$ evokes a corkscrew-like rolling behavior, evoked in as little as $0.4 \mathrm{~s}$ (Tracey et al. 2003). Strong mechanical stimulation evokes a similar behavior, indicating that this might be a nociceptive response to damaging stimuli. The sensory neurons required for this response are the class IV multidendritic neurons that terminate in the periphery of the larvae, attached to epidermal cells (Hwang et al. 2007). Proof that they function as nociceptors came from experiments where channelrhodopsin-2 was expressed in different multidendritic neuron classes and behavior observed upon photoactivation. Only activation in class IV neurons caused nocifensive rolling, whereas activation in classes II and III neurons evoked an accordion-like behavior indicative of a role in propagating muscle contraction during peristaltic locomotion, not nociception (Hwang et al. 2007). Closer examination of the rolling behavior indicated that, somewhat counter 
intuitively, larvae roll toward the stimulus. However, this behavior appears to have evolved as a defense mechanism in response to parasitoid wasps, which penetrate D. melanogaster larvae with their ovipositors. When Leptopilina boulardi wasps attack D. melanogaster, the larvae do indeed roll toward the side of attack, resulting in the ovipositor becoming wrapped around the larva, which as it continues to roll carries the wasp up into the air and on to its back (Hwang et al. 2007). This defensive behavior explains the need for a sensory receptor capable of responding to noxious mechanical stimulation. However, an example of natural danger with respect to noxious thermal stimulation has not been identified. Screening identified the painless gene as being necessary for the detection of noxious heat in larvae (Tracey et al. 2003) and there must clearly be evolutionary pressure to conserve such thermal sensitivity because adult $D$. melanogaster have also been shown to demonstrate a painless-dependent nociceptive jumping behavior to temperatures $>45^{\circ} \mathrm{C}$ (Xu et al. 2006). Painless encodes for a TRP ion channel that is an evolutionary homolog of the mammalian TRPA1. Therefore, it is not surprising that both of these ion channels are activated by isothioscyanate, which causes the burning associated with wasabi (a member of the Brassicaceae plant family, a paste of which is often served with sushi) and is a repellant for D. melanogaster (Jordt et al. 2004; Al-Anzi et al. 2006). Expression of the painless cDNA in a mammalian cell line has shown that, in agreement with behavioral studies, the ion channel protein encoded by painless, has a thermal threshold of $42.6^{\circ} \mathrm{C}$ for activation (Sokabe et al. 2008). However, much controversy surrounds the putative mammalian ortholog of painless, TRPA1. Unlike painless, TRPA1 was initially described to be cold-activated (Story et al. 2003), however, this finding was not replicated by other groups (Jordt et al. 2004) and similar discrepancies were identified when examining the behavioral phenotypes of TRPA $1^{-l-}$ mice (Bautista et al. 2006; Kwan et al. 2006). Importantly, recordings from sensory neurons in TRPA $1^{-1-}$ mice suggest that TRPA1 is not necessary for nociceptors to detect cold (Kwan et al. 2009). Indeed, cold has been shown to indirectly activate TRPA1 via inducing a calcium influx, which then activates the channel (Zurborg et al. 2007) although evidence for calcium-independent activation after prolonged cold has been found (Karashima et al. 2009).

To conclude this section on invertebrates, it would appear that with the evolution of bilateralism and a more structured nervous system that the development of neurons specialized in detecting noxious stimuli has occurred. The next step in nociceptor evolution saw the development of different classes of nociceptors, as observed in vertebrates.

\section{Lower vertebrates and nociceptor specialization}

\section{Petromyzontidae}

Perhaps, the oldest living ancestors of fish are the Petromyzontidae (lamprey), although where this family of animals should be grouped is still rather contentious. Molecular datasets infer monophylogeny with the other extant agnathan, the hagfish, whereas phenotypic analysis implies monophylogeny with Gnathostomata (jawed animals). A recent phylogenetic analysis combining phenotypic and molecular data concluded that monophyly of agnathans based upon molecular data should at least be viewed with some skepticism (Near 2009). The sea lamprey Petromyzon marinus, has no myelinated nerve fibers and assessment of its sensory nervous system revealed similar findings to those in the leech. Recordings from both trigeminal neurons and first-order sensory neurons in the spinal cord, in response to cutaneous stimulation, identified low threshold, rapidly adapting T-cells; P-cells that varied in sensitivity, some being as sensitive as T-cells, but slower adapting after stimulation; and $\mathrm{N}$-cells, which required severe indentation of the skin to be activated. Puncturing the skin with a pin or squeezing with forceps produced the greatest $\mathrm{N}$-cell activation that, like that of P-cells, was slowly adapting (Martin and Wickelgren 1971; Matthews and Wickelgren 1978). As also observed in the leech, P. marinus N-cells could be activated by heat strong enough to burn the skin, in keeping with their putative nociceptive function (Martin and Wickelgren 1971; Matthews and Wickelgren 1978; Pastor et al. 1996). It has also been observed that P-cells could also be activated by warming, but the activation threshold was lower than that of the nociceptive N-cells. Cooling was also examined, but was not found to stimulate any cell type (Martin and Wickelgren 1971).

\section{Elasmobranchii and Teleostei}

Research on nociception in fish has focused on two main groups, the Elasmobranchii (cartilaginous fish, such as sharks) and Teleostei (ray-finned, bony fish, such as trout). Anatomically it would seem that Elasmobranchii are ill equipped to sense noxious stimuli because in a wide variety of ray and shark species very few unmyelinated nerve fibers, compared to myelinated fibers, have been observed, the opposite to the situation in mammals (Coggeshall et al. 1978; Snow et al. 1993). Unlike in rodents where a bimodal distribution of DRG cell body diameter accounting for A- and C-fibers is observed, DRG cell body diameters in the elasmobranch fish were found to be unimodal (Snow et al. 1993). Additionally, an electrophysiological study has found that stingrays lack typical polymodal nociceptive 
neurons (Leonard 1985). Furthermore, the observation that injured sharks can keep feeding until either dead or torn to pieces by other sharks has been suggested as evidence that they do not sense their injuries as noxious (Goadby 1959; Snow et al. 1993).

More in-depth knowledge has been gathered on Teleostei, where the occurrence of free nerve endings, suggestive of nociceptors, has long been known (Whitear 1971). A recent examination of sensory afferents in the trigeminal nerve of the rainbow trout, Oncorhynchus mykiss, has identified the same range of fiber types as present in mammals (Sneddon 2002). The finding of both myelinated and a significant number of unmyelinated nerve fibers in a teleost fish is proposed to represent evolutionary divergence between elasmobranch fish, which have largely lost unmyelinated fibers, and the teleost fish, which like higher vertebrates have both unmyelinated and myelinated fibers (Sneddon 2004). Two electrophysiology studies have been published, where recordings were made from the trigeminal nerve in response to cutaneous stimulation and nociceptor classes similar to those in mammals were identified (Sneddon 2003b; Ashley et al. 2007). Three types of nociceptor were observed: mechanothermal nociceptors, mechanochemical nociceptors and polymodal nociceptors, which could be activated by mechanical, heat and acidic stimuli. All the C-fiber afferents recorded from rainbow trout demonstrated tonic firing when stimulated and higher mechanical thresholds compared to those of the two groups of mechanoreceptors identified (Ashley et al. 2007). However, the mechanical thresholds observed were very low compared to cutaneous mammalian nociceptors. However, mammalian nociceptors with a low threshold are known to innervate the mammalian cornea, a tissue with both a low pain threshold and low threshold polymodal nociceptors ( $\sim 44 \mathrm{mg}$; Belmonte and Giraldez 1981). Thus, it might be speculated that the high mechanical sensitivity of fish mechanonociceptors is a compensatory feature due to the more easily damageable nature of their skin (Sneddon 2003b). The thermal threshold of $\sim 33^{\circ} \mathrm{C}$, which was considered as noxious (Ashley et al. 2007), is $\sim 10^{\circ} \mathrm{C}$ lower than the activation threshold of mammalian nociceptors (Cain et al. 2001). When examining cold sensitivity it was found that none of the nociceptors responded, even at temperatures as low as $-7^{\circ} \mathrm{C}$. It has been proposed that poikilothermic fish have no need for cold sensitivity, especially when considering that some species live at temperatures bordering on freezing, whereas homeothermic animals are under pressure to maintain a constant body temperature and so the ability to sense cold temperature as painful is potentially advantageous (Ashley et al. 2007). In addition the overwhelming majority of putative nociceptors recorded in $O$. mykiss were thinly myelinated $\mathrm{A} \delta$-mechanonociceptors, in agreement with the low abundance of $\mathrm{C}$-fibers identified by electron microscopy (Sneddon 2002). Behavioral tests have also been conducted with $O$. mykiss, in which injection of acid or bee venom into the frontal lips produced several effects: increased opercular beat rate, rocking behavior, increased time until resumption of normal feeding. Acid also induced rubbing of the lips against the gravel floor (Sneddon et al. 2003). There has, however, been some debate about conclusions from this study, particularly due to claims made that the fish were experiencing pain as opposed to exhibiting purely nociceptive responses (Rose 2003). Although not tested, in $O$. mykiss, thermonociception has been recently assessed behaviorally in the goldfish, Carassius auratus. Testing found that the temperature required to elicit an escape response and, thus, presumably to activate nociceptors was $38^{\circ} \mathrm{C}$, which correlates well with the critical maximum temperature of $C$. auratus being $\sim 38^{\circ} \mathrm{C}$ (Ford and Beitinger 2005; Nordgreen et al. 2009). Morphine had no effect on the temperature threshold for escape initiation in C. aurutus, but has been observed to relieve acid-mediated pain in $O$. mykiss suggesting that more research is required to gain a better understanding of the role of opioids in pain signaling in fish (Sneddon 2003a; Nordgreen et al. 2009).

\section{Amphibia}

The evolution of fins into legs permitted the ancestors of today's amphibians to move onto land, where they would be challenged by a novel environment. Nociception has been extensively studied in the Northern grass frog, Rana pipiens. A behavioral test was initially developed, whereby topical application of acetic acid induced wiping of the skin (Pezalla 1983) and was then further developed to allow for testing of both thermo- and mechanonociception (Willenbring and Stevens 1996). Withdrawal thresholds/latency to all stimuli were increased by morphine, in a manner inhibited by naloxone, suggesting that, as in mammals, an opioid system exists for modulating nociceptive signals (Willenbring and Stevens 1996). Topical application of very low $\mathrm{pH} \quad(\mathrm{pH}<2.5)$ was required to generate behavioral responses, but the subepidermal $\mathrm{pH}$ produced by such a stimulus is $\sim 6.7$, a $\mathrm{pH}$, which activates mammalian nociceptors and induces pain in humans (Steen et al. 1992; Hamamoto et al. 2000; Ugawa et al. 2002). Characterization of cutaneous nociceptors identified both $\mathrm{A} \delta$-nociceptors and polymodal $\mathrm{C}$-fiber nociceptors, the latter having thermal thresholds of $\sim 40^{\circ} \mathrm{C}$ and $\sim 7^{\circ} \mathrm{C}$ for heat and cold, respectively, values that are similar to those found in mammals (Cain et al. 2001; Hamamoto and Simone 2003).

\section{Reptilia and Aves}

The last classes of vertebrates that will briefly be discussed are the Reptilia and Aves. There is limited published data 
pertaining to nociception in Reptilia, but cutaneous fibers in the trigeminal ganglia in crotaline snakes have been recorded. $\mathrm{A} \beta$-fibers were shown to respond to non-noxious mechanical stimuli and to have larger somata, whereas $\mathrm{A} \delta$ fibers responding to noxious mechanical stimulation have smaller somata (Liang et al. 1995). Some nociceptors had action potentials with humps on the repolarization phase like mammalian nociceptors (Liang and Terashima 1993). Very limited evidence also suggests the presence of mechanonociceptors in the cutaneous plantar nerve of the alligator, Alligator mississippiensis, some of which respond to a noxious thermal stimulus $>\sim 40^{\circ} \mathrm{C}$ (Kenton et al. 1971).

The skin-nerve preparation that has proved useful for characterizing mammalian sensory afferents has also been adapted to the chick (Koltzenburg and Lewin 1997). Cfibers from hatchlings had higher von Frey thresholds than A-fibers $(5.7 \mathrm{mN}$ vs. $2.4 \mathrm{mN})$ and $32 \%$ were activated by heat, of which $8 \%$ were also activated by cold. Application of an inflammatory soup resulted in sensitization, most C-fibers gave an increased response to heat and $21 \%$ of $\mathrm{C}$-fibers became heat-sensitive. The presence of mechanonociceptive C-fibers, which also respond to heat, have also been identified in the parafibular nerve that innervates scaly skin on the lower leg. The threshold was determined as $\sim 49^{\circ} \mathrm{C}$, which is relatively high and probably due to the insulating nature of the thick scaly skin (Gentle et al. 2001). Indeed a threshold closer to that in mammals of $\sim 45^{\circ} \mathrm{C}$ has been recorded in the beak (Gentle 1989) and of $\sim 47^{\circ} \mathrm{C}$ in the radial nerve innervating feathered skin of the pigeon (Necker and Reiner 1980). Although it has not been tested in teased fiber recordings, chick DRG cells are insensitive to capsaicin (Wood et al. 1988), correlating with capsaicin insensitivity of cloned chick TRPV1 (Jordt and Julius 2002).

Within vertebrates, we therefore see the evolution from an invertebrate-like, unmyelinated nervous system in the lamprey (which displays noxious mechanical and heat sensitivity) to fish where myelinated nociceptors are first observed. In mammals detailed examination has identified a variety of nociceptors, with a central role for the polymodal nociceptor, which can be activated by noxious heat, cold, mechanical and chemical stimuli. A summary of nociceptor evolution is illustrated in Fig. 4.

\section{Do common molecular mechanisms underlie nociceptor activation across the tree of life?}

Possession of nociceptors has evolved alongside increased organism complexity, presumably conferring an evolutionary advantage to Eumetazoa. The emerging picture is that mammals have a more diverse array of nociceptors than

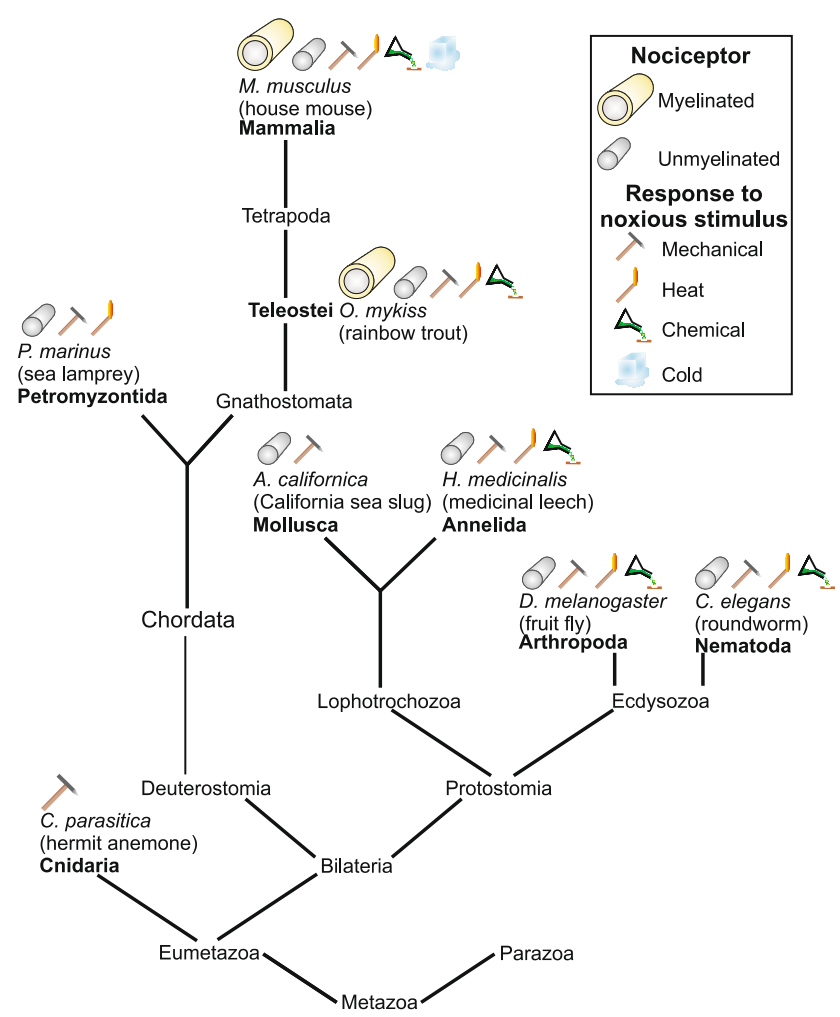

Fig. 4 The acquisition of different capabilities by nociceptors from an evolutionary viewpoint, starting with Cnidaria with an ability to sense a noxious mechanical stimulus, but no defined nociceptors, and ending with mammals, which have both myelinated and unmyelinated nociceptors capable of detecting a wide range of mechanical, thermal and chemical (acid, capsaicin etc.) stimuli. The graph is not fully conclusive because to our knowledge not all species have been examined for sensitivity to all stimuli, for example $P$. marinus $\mathrm{N}$-cells have not been tested for either capsaicin or acid sensitivity

invertebrates although insufficient data in non-mammalian species makes a full comparison difficult. For example, investigations that include examining the response of a nociceptor to all stimuli (mechanical, cold, heat and chemical) are often lacking. However, in view of the available information, can any similar mechanisms of nociceptor function throughout evolution be identified? For example, the G-protein coupled receptor rhodopsin is found to be involved in phototransduction both in invertebrates and in vertebrates (Frings 2009) and the question is if similar evolutionary similarities exist in terms of how nociceptors detect noxious stimuli. The TRP ion channel family features in many sensory pathways and, as discussed below, TRP proteins are involved in nociceptor function. The family name arose from identification of the first member of this family, which is responsible for the transient response to bright illumination in photoreceptors of a Drosophila mutant (Cosens and Manning 1969; Montell and Rubin 1989). 


\section{Mechanonociception}

Neurons responding to noxious mechanical stimuli have been identified in the invertebrate phyla Mollusca and Annelida (Nicholls and Baylor 1968; Walters et al. 1983). Behavioral experimentation suggests the likely presence of mechanonociceptors in acoelomate Bilateria (Koopowitz 1973) and possibly Radiata (Passano and Pantin 1955) making it likely that this is the most ancient nociceptive trait. However, at the moment there is no electrophysiological data to confirm the presence of mechanonociceptors in these species. Unfortunately for most invertebrates there is little molecular data regarding what proteins might be involved in transducing noxious mechanical stimuli. However, an abundance of such data has been generated from studies with C.elegans and to a lesser extent D. melanogaster.

At the core of the transduction mechanism is a mechanosensitive ion channel which is opened directly by mechanical force. Based on genetic screens and electrophysiology in $C$. elegans, a model has been proposed in which a channel complex is linked to both the cytoskeleton and extracellular matrix (for a recent review see Chalfie 2009). The ion channel subunits in this structure are members of the DEG/ $\mathrm{ENaC}$ (degenerin/epithelial $\mathrm{Na}^{+}$channel) family, which includes ASICs. Whereas D. melanogaster larvae lacking the DEG/ENaC homolog Pickpocket-1 have normal touch sensation (Ainsley et al. 2003) mice lacking ASIC3 have reduced cutaneous nociceptor sensitivity (Price et al. 2001), although mechanosensitive currents in cultured DRGs from these mice are not different from those in wild-type DRGs (Drew et al. 2004; Lechner et al. 2009). Overall, much evidence supports a role for ASICs in mechanosensation, but their exact function in the transduction process remains unclear (Price et al. 2000, 2001; Page et al. 2004, 2005; Jones et al. 2005). Proteins homologous to those in C. elegans, which bind to and modulate the physiological properties of ASICs have also been identified in mice. SLP3 is an example of a protein that is highly orthologous to MEC-2, which is thought to be essential for function of the mechanosensitive ion channel complex formed by MEC4/MEC10 in C. elegans (Huang et al. 1995; Goodman et al. 2002; O'Hagan et al. 2005). SLP3 can modulate ASIC channels in heterologous expression systems and deletion of the SLP3 gene also changes the physiological activity of ASIC channels in cultured DRG neurons (Wetzel et al. 2007). However, more interestingly, the loss of SLP3 in mice results in a range of fibers, including $\mathrm{A} \delta$-mechanonociceptors, becoming insensitive to mechanical stimulation (Wetzel et al. 2007). In addition, genetic deletion of the highly related stomatin gene decreases non-mechanonociceptive D-hair fiber sensitivity (Martinez-Salgado et al. 2007).
The TRP channels have also been proposed to play a role in mechanosensation and the painless gene, in D. melanogaster, has received much attention. Studies of the mammalian homolog, TRPA1, have produced conflicting findings; TRPA $1^{-l-}$ mice have been shown to display decreased behavioral sensitivity to punctate mechanical stimulation (Kwan et al. 2006), but with no change in mechanical withdrawal threshold (Bautista et al. 2006). Although TRPA $1^{-1-}$ C-fibers fire action potentials less frequently in response to mechanical stimulation, firing frequency was seen to either increase or decrease in other fiber types as well, some of which do not express TRPA1 protein. These data suggest that TRPA1 is not itself directly involved in mechanotransduction and that any involvement is not specific to mechanonociception (Kwan et al. 2009). TRPV channels are also implicated in mechanosensation, spawned by the finding that a C. elegans TRP, OSM-9, is involved in mechanosensation (Colbert et al. 1997). The nearest mammalian ortholog of OSM-9 is thought to be TRPV4. Pharmacological and knock-down studies have suggested that TRPV4 plays a role in mechanical hyperalgesia and, therefore, nociceptor sensitization, as opposed to the direct transduction of noxious mechanical stimuli (Alessandri-Haber et al. 2003, 2008, 2009; Grant et al. 2007). Indeed, the mechanical threshold for C-fibers from TRPV4 ${ }^{-l-}$ mice is the same as in wild-type mice, thus, arguing against TRPV4 being the mechanotransducer (Chen et al. 2007). Finding the identity of the mammalian mechanotransduction channel in nociceptors is, thus, a key research goal with no ion channel having been shown to be responsible for the transduction current itself in contrast to MEC4 in C. elegans touch neurons (O'Hagan et al. 2005; Hu et al. 2006).

Heat

Electrophysiological data demonstrate that the temperature threshold for nociceptors to respond to noxious heat varies from $\sim 33^{\circ} \mathrm{C}$ in $O$. mykiss (Ashley et al. 2007) to $\sim 49^{\circ} \mathrm{C}$ in the scaly skin of the chick (Gentle et al. 2001). This would suggest that there is not one evolutionary conserved noxious heat sensor. In terms of the molecular identity of a potential heat sensor in mammals, excitement abounded when the capsaicin receptor TRPV1 was cloned from rat DRGs and shown to have a threshold of $\sim 43^{\circ} \mathrm{C}$ (Caterina et al. 1997; Tominaga et al. 1998), very similar to the heatgated current identified in cultured rat DRG neurons (Cesare and McNaughton 1996). However, although heat activated currents at $\sim 43^{\circ} \mathrm{C}$ were absent from TRPV $1^{-/-}$ DRG neurons, heat-sensitive $\mathrm{C}$-fibers, although less numerous, still had an activation threshold not different from wild-type animals; moreover, withdrawal latencies in a variety of tests were unchanged until $50^{\circ} \mathrm{C}$ was reached, 
which is much higher than the TRPV1 activation threshold (Caterina et al. 2000). One study found no difference even at $52.5^{\circ} \mathrm{C}$ (Davis et al. 2000). Therefore, although TRPV1 is activated at a similar temperature to that which also activates nociceptors it is clearly not essential for this process and is not the only protein involved in heat activation of nociceptors. Indeed, it has been convincingly demonstrated that there is no change in polymodal $\mathrm{C}$-fiber heat-activation threshold or response properties in TRPV $1^{-/-}$mice (Woodbury et al. 2004; Lawson et al. 2008). Furthermore, immunostaining for TRPV1 labeled only DRG cell bodies belonging to $\mathrm{C}$-heat fibers $(\mathrm{CH})$, whereas it was absent in polymodal $\mathrm{C}$-fibers and correspondingly no $\mathrm{CH}$ fibers were found in TRPV1 ${ }^{-l-}$ mice (Lawson et al. 2008). Taking all this evidence into consideration the role of TRPV1 as a noxious heat sensor is likely to be minor at most. There is, however, no doubt that TRPV1 is essential for the phenomenon of thermal hyperalgesia and is furthermore the only ion channel known to be activated by capsaicin (Caterina et al. 2000; Davis et al. 2000; Huang et al. 2006a). With this in mind the capsaicin sensitivity, although low, of N-cells in H. medicinalis is likely due to a TRPV1-like molecule although no such ion channel has yet been cloned.

\section{Cold}

Noxious cold sensitivity appears to have evolved more recently than noxious heat sensitivity, only emerging when animals began to live on the land. As discussed previously, there is an ongoing debate about the ability of noxious cold to activate TRPA1 (Caspani and Heppenstall 2009; Kwan and Corey 2009) and behavioral studies in knockout mice have produced conflicting results (Bautista et al. 2006; Kwan et al. 2006; Karashima et al. 2009). Importantly TRPA $^{-/-}$cutaneous $C$-fiber nociceptors demonstrate no difference in cold sensitivity compared to wild-type mice, supporting the argument that TRPA1 is not a transducer of acute noxious cold (Kwan et al. 2009). A further candidate is the menthol-gated TRPM8 ion channel, although this is activated at cool $\left(\sim 26^{\circ} \mathrm{C}\right)$, rather than cold temperatures (McKemy et al. 2002) higher than the thresholds for nociceptor activation in mice (Cain et al. 2001) and cold pain in humans (Davis and Pope 2002). Depending upon the paradigm used, most studies find that TRPM $8^{-1-}$ mice have deficits in cold-induced behaviors, but that noxious cold still evokes behaviors similar to wild-type mice indicating the likelihood of another cold-activated ion channel (Bautista et al. 2007; Dhaka et al. 2007). How noxious cold directly activates nociceptors is still a very gray area as has been recently reviewed (Reid 2005), with non-TRP channels certainly being involved (Babes et al. 2006; Madrid et al. 2009).
Acid

The burning pain associated with acid is well known to anyone who has had the misfortune to get lemon juice/vinegar into an open wound in the skin. Acid-activated nociceptors are not, however, specific to mammalian species, $H$. medicinalis being perhaps the most simple organism where nociceptor activation by acid has been demonstrated (Pastor et al. 1996). Both TRPV1 (Tominaga et al. 1998) and ASICs, with the exception of ASIC2b and ASIC4 (Hesselager et al. 2004), are activated by acid and the use of drugs that block ASICs in humans can partially relieve acid-induced pain (Ugawa et al. 2002; Jones et al. 2004). Cfibers from $\mathrm{ASIC}^{-1-}$ mice also fire less action potentials in response to a $\mathrm{pH} 5.0$ stimulus compared to wild-type mice (Fig. 5; Price et al. 2001). However, there are numerous problems with the argument that ASICs are responsible for acid-induced nociceptor activation: (1) licking behavior in response to paw injection of acid is not different in $\mathrm{ASIC}^{-/-}$ mice (Price et al. 2001); (2) ASIC2b and ASIC4 are not gated by protons (Lingueglia et al. 1997; Akopian et al. 2000; Smith et al. 2007b); (3) the ASIC gene from the invertebrate sea-squirt, Ciona intestinalis, does not encode a proton-sensitive ion channel (Coric et al. 2008) and (4) only in teleost fish does ASIC proton-sensitivity begin to occur; shark and lamprey, which branch-off earlier in evolution possess ASIC genes encoding non-proton sensitive ion channels (Coric et al. 2005). From these last two points one might predict that ASICs encoded by the invertebrate $H$. medicinalis would, therefore, also be proton insensitive, thus, suggesting an alternative mechanism by which $\mathrm{N}$-cells are activated by acid.

An unusual species, which might prove useful as a tool in identifying the mechanism of acid-mediated nociceptor activation is the African naked mole-rat $H$. glaber the C-fibers of which are not activated by acid (see Fig. 5; Park et al. 2008). This acid insensitivity at the behavioral and nociceptor level is unique in Animalia as far back as fish. Naked mole-rats live in large colonies (up to 300 animals, Brett 1991), in chambers that are congested and poorly ventilated, which would result in high carbon dioxide levels. High levels of carbon dioxide are known to be noxious (Anton et al. 1992) and can activate $\mathrm{C}$-fibers through induction of tissue acidosis (Steen et al. 1992). In view of this we have postulated that high ambient carbon dioxide levels in the burrows of a naked mole-rat ancestor might have produced selective pressure to abolish acid activation of nociceptors (Park et al. 2008). Identifying the neuronal differences between H. glaber and other rodents could help identify the mechanism by which protons activate nociceptors in other species. 

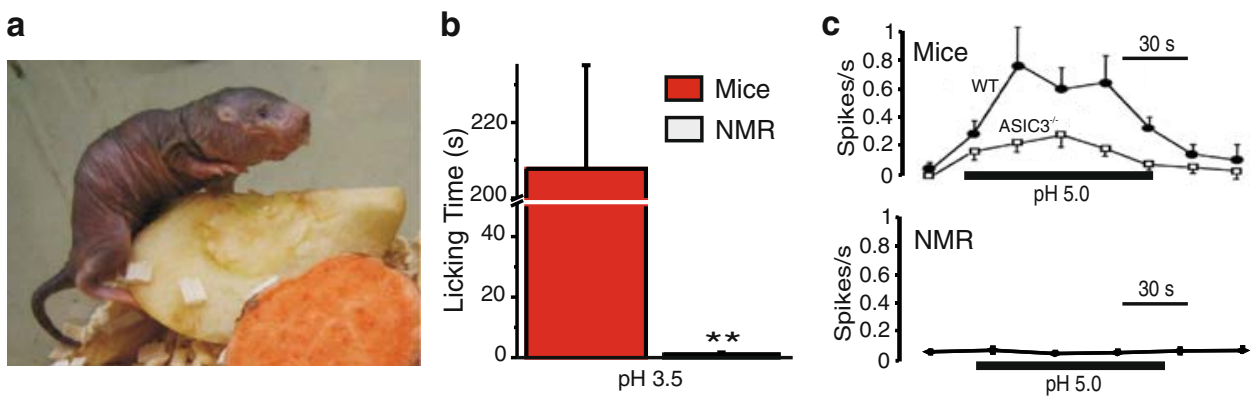

Fig. 5 The African naked mole-rat (NMR) H. glaber (a) does not display any nociceptive behavior in response to foot pad injection of acidic saline, which evokes vigorous licking behavior in the mouse (b). c sensory neurons from saphenous nerve in the naked mole-rat display no activity when stimulated with an acidic solution (lower panel, data

\section{Electrical activity}

As has been discussed, a feature that is often described as characteristic of nociceptors is an inflection or hump on the repolarization phase of the action potential. This would suggest that there are common components underlying the electrical activity in nociceptors in different species. In mammals activation of an ion channel by a noxious stimulus produces a generator potential, which depolarizes the cell. Depolarization of significant magnitude activates voltage-gated sodium channels $(\mathrm{NaV})$ and an action potential is induced. A diverse range of $\mathrm{NaV}$ currents are present in mammalian nociceptors, most of which are inhibited by tetrodotoxin (TTX), although two neuronal subunits, predominantly expressed in nociceptors, are TTX-resistant: NaV1.8 and 1.9 (reviewed by Rush et al. 2007; Momin and Wood 2008). The degree to which the electronic machinery is shared between mammals and other Animalia is not known. In H. medicinalis both TTX-sensitive and -resistant currents have been identified and, unlike in mammalian nociceptors, where the TTX-resistant NaV1.8 is a key player in action potential generation, $\mathrm{N}$-cell action potentials are TTX-sensitive (Kleinhaus and Prichard 1983; Renganathan et al. 2001). TTX-sensitivity is not relevant in C. elegans because no genes encoding $\mathrm{NaV}$ channels are present in the genome, action potentials probably not being necessary due to the small diameter, high-resistance nature of their neurons (Bargmann 1998). However, a recent debate has emerged in the literature about whether certain C. elegans neurons are indeed capable of action potential generation (Mellem et al. 2008, 2009; Lockery and Goodman 2009; Lockery et al. 2009). As has been frequently mentioned, in those organisms where nociceptor-like action potentials do occur, it has often been reported that an inflection occurs in the repolarization phase and in rat DRG neurons this may largely be due to a combination of TTX-resistant $\mathrm{NaV}$ and high voltage-activated calcium channels (Blair and Bean 2002). adapted from Park et al. 2008), whereas those in WT mice (upper panel, filled square) fire action potentials throughout the stimulus, a decreased rate being recorded in $\mathrm{ASIC}^{-1-}$ mice (open square) (Price et al. 2001). Photo E. St. J. Smith

\section{Conclusions}

The mammalian sensory system is equipped with an array of sensory neurons including $\mathrm{A} \delta$-mechanonociceptors, Cfiber polymodal nociceptors and other C-fiber nociceptors. The evolution of the nervous system in an ancestor of Cnidaria enabled multicellular organisms to efficiently detect and respond to environmental stimuli and the presence of nociceptors, those neurons dedicated to detecting noxious stimuli, has been identified in invertebrates, such as $H$. medicinalis and A. californica. Most vertebrates have both myelinated and unmyelinated nociceptors, which has allowed for the further diversification and increased complexity of nociceptor function, which is indicated by many nociceptor classes that exist in the mammalian nervous system. Although certain molecules involved in the detection of noxious stimuli have been identified, we are still a long way from understanding how nociceptors really function and considering the conserved nature of certain nociceptor properties, a comparative approach should help to further define what ion channels and receptors are involved.

Acknowledgments We would like to thank Dr. Thomas J. Park for helpful discussion, Drs. Kate Poole and Stefan G. Lechner for critical reading of the manuscript and reviewers of this manuscript for their insightful comments. E. St. J. S. holds a Fellowship from the Alexander von Humboldt foundation.

Open Access This article is distributed under the terms of the Creative Commons Attribution Noncommercial License which permits any noncommercial use, distribution, and reproduction in any medium, provided the original author(s) and source are credited.

\section{References}

Adriaensen H, Gybels J, Handwerker HO, Van Hees J (1980) Latencies of chemically evoked discharges in human cutaneous nociceptors and of the concurrent subjective sensations. Neurosci Lett 20:55-59 
Ainsley JA, Pettus JM, Bosenko D, Gerstein CE, Zinkevich N, Anderson MG, Adams CM, Welsh MJ, Johnson WA (2003) Enhanced locomotion caused by loss of the Drosophila DEG/ENaC protein Pickpocket1. Curr Biol 13:1557-1563

Akopian AN, Chen CC, Ding Y, Cesare P, Wood JN (2000) A new member of the acid-sensing ion channel family. Neuroreport 11:2217-2222

Al-Anzi B, Tracey WD Jr, Benzer S (2006) Response of Drosophila to wasabi is mediated by painless, the fly homolog of mammalian TRPA1/ANKTM1. Curr Biol 16:1034-1040

Albers KM, Woodbury CJ, Ritter AM, Davis BM, Koerber HR (2006) Glial cell-line-derived neurotrophic factor expression in skin alters the mechanical sensitivity of cutaneous nociceptors. J Neurosci 26:2981-2990

Alessandri-Haber N, Yeh JJ, Boyd AE, Parada CA, Chen X, Reichling DB, Levine JD (2003) Hypotonicity induces TRPV4-mediated nociception in rat. Neuron 39:497-511

Alessandri-Haber N, Dina OA, Joseph EK, Reichling DB, Levine JD (2008) Interaction of transient receptor potential vanilloid 4, integrin, and SRC tyrosine kinase in mechanical hyperalgesia. J Neurosci 28:1046-1057

Alessandri-Haber N, Dina OA, Chen X, Levine JD (2009) TRPC1 and TRPC6 channels cooperate with TRPV4 to mediate mechanical hyperalgesia and nociceptor sensitization. J Neurosci 29:62176228

Anton F, Euchner I, Handwerker HO (1992) Psychophysical examination of pain induced by defined $\mathrm{CO} 2$ pulses applied to the nasal mucosa. Pain 49:53-60

Ashley PJ, Sneddon LU, McCrohan CR (2007) Nociception in fish: stimulus-response properties of receptors on the head of trout Oncorhynchus mykiss. Brain Res 1166:47-54

Babes A, Zorzon D, Reid G (2006) A novel type of cold-sensitive neuron in rat dorsal root ganglia with rapid adaptation to cooling stimuli. Eur J Neurosci 24:691-698

Baccaglini PI, Hogan PG (1983) Some rat sensory neurons in culture express characteristics of differentiated pain sensory cells. Proc Natl Acad Sci USA 80:594-598

Bargmann CI (1998) Neurobiology of the Caenorhabditis elegans genome. Science 282:2028-2033

Barr MM, Garcia LR (2006) Male mating behavior. WormBook:1-11

Bautista DM, Jordt SE, Nikai T, Tsuruda PR, Read AJ, Poblete J, Yamoah EN, Basbaum AI, Julius D (2006) TRPA1 mediates the inflammatory actions of environmental irritants and proalgesic agents. Cell 124:1269-1282

Bautista DM, Siemens J, Glazer JM, Tsuruda PR, Basbaum AI, Stucky CL, Jordt SE, Julius D (2007) The menthol receptor TRPM8 is the principal detector of environmental cold. Nature 448:204-208

Belmonte C, Giraldez F (1981) Responses of cat corneal sensory receptors to mechanical and thermal stimulation. J Physiol 321:355-368

Bessou P, Perl ER (1969) Response of cutaneous sensory units with unmyelinated fibers to noxious stimuli. J Neurophysiol 32:10251043

Billy AJ, Walters ET (1989) Modulation of mechanosensory threshold in Aplysia by serotonin, small cardioactive peptideB (SCPB), FMRFamide, acetylcholine, and dopamine. Neurosci Lett 105:200-204

Binshtok AM, Wang H, Zimmermann K, Amaya F, Vardeh D, Shi L, Brenner GJ, Ji RR, Bean BP, Woolf CJ, Samad TA (2008) Nociceptors are interleukin-1beta sensors. J Neurosci 28:14062-14073

Blair NT, Bean BP (2002) Roles of tetrodotoxin (TTX)-sensitive $\mathrm{Na}^{+}$ current, TTX-resistant $\mathrm{Na}^{+}$current, and $\mathrm{Ca}^{2+}$ current in the action potentials of nociceptive sensory neurons. J Neurosci 22:1027710290

Brett R (1991) The population structure of naked mole-rat colonies. In: Sherman PW, Jarvis JUM, Alexander RD (eds) The biology of the naked mole rat. Princeton University Press, Princeton (New Jersey), pp 97-136

Brierley SM, Jones RC 3rd, Gebhart GF, Blackshaw LA (2004) Splanchnic and pelvic mechanosensory afferents signal different qualities of colonic stimuli in mice. Gastroenterology 127:166178

Bullock TH, Horridge GA (1965) Structure and function in the nervous system of invertebrates. W. H. Freeman and Co., San Francisco

Burgess PR, Perl ER (1967) Myelinated afferent fibres responding specifically to noxious stimulation of the skin. J Physiol 190:541-562

Byrne J, Castellucci V, Kandel ER (1974) Receptive fields and response properties of mechanoreceptor neurons innervating siphon skin and mantle shelf in Aplysia. J Neurophysiol 37:1041-1064

Cadiou H, Studer M, Jones NG, Smith ES, Ballard A, McMahon SB, McNaughton PA (2007) Modulation of acid-sensing ion channel activity by nitric oxide. J Neurosci 27:13251-13260

Cain DM, Khasabov SG, Simone DA (2001) Response properties of mechanoreceptors and nociceptors in mouse glabrous skin: an in vivo study. J Neurophysiol 85:1561-1574

Caspani O, Heppenstall PA (2009) TRPA1 and cold transduction: an unresolved issue? J Gen Physiol 133:245-249

Castellucci V, Pinsker H, Kupfermann I, Kandel ER (1970) Neuronal mechanisms of habituation and dishabituation of the gill-withdrawal reflex in Aplysia. Science 167:1745-1748

Caterina MJ, Schumacher MA, Tominaga M, Rosen TA, Levine JD, Julius D (1997) The capsaicin receptor: a heat-activated ion channel in the pain pathway. Nature 389:816-824

Caterina MJ, Leffler A, Malmberg AB, Martin WJ, Trafton J, PetersenZeitz KR, Koltzenburg M, Basbaum AI, Julius D (2000) Impaired nociception and pain sensation in mice lacking the capsaicin receptor. Science 288:306-313

Cavelier-Smith T, Allsopp MTEP, Chao N, Boury-Esnault N, Vacelet J (1996) Sponge phylogeny, animal monophyly, and the origin of the nervous system: 18S rRNA evidence. Can J Zool 74:20312045

Cesare P, McNaughton P (1996) A novel heat-activated current in nociceptive neurons and its sensitization by bradykinin. Proc Natl Acad Sci USA 93:15435-15439

Chalfie M (2009) Neurosensory mechanotransduction. Nat Rev Mol Cell Biol 10:44-52

Chen X, Alessandri-Haber N, Levine JD (2007) Marked attenuation of inflammatory mediator-induced C-fiber sensitization for mechanical and hypotonic stimuli in TRPV4 ${ }^{-1-}$ mice. Mol Pain 3:31

Coggeshall RE, Leonard RB, Applebaum ML, Willis WD (1978) Organization of peripheral nerves and spinal roots of the Atlantic stingray, Dasyatis sabina. J Neurophysiol 41:97-107

Colbert HA, Smith TL, Bargmann CI (1997) OSM-9, a novel protein with structural similarity to channels, is required for olfaction, mechanosensation, and olfactory adaptation in Caenorhabditis elegans. J Neurosci 17:8259-8269

Coric T, Zheng D, Gerstein M, Canessa CM (2005) Proton sensitivity of ASIC1 appeared with the rise of fishes by changes of residues in the region that follows TM1 in the ectodomain of the channel. J Physiol 568:725-735

Coric T, Passamaneck YJ, Zhang P, Di Gregorio A, Canessa CM (2008) Simple chordates exhibit a proton-independent function of acid-sensing ion channels. Faseb J 22(6):1914-1923

Cosens DJ, Manning A (1969) Abnormal electroretinogram from a Drosophila mutant. Nature 224:285-287

Darwin C (1859) On the origin of species by means of natural selection, or the preservation of favoured races in the struggle for life. John Murray, London

Davis KD, Pope GE (2002) Noxious cold evokes multiple sensations with distinct time courses. Pain 98:179-185

Davis JB, Gray J, Gunthorpe MJ, Hatcher JP, Davey PT, Overend P, Harries MH, Latcham J, Clapham C, Atkinson K, Hughes SA, 
Rance K, Grau E, Harper AJ, Pugh PL, Rogers DC, Bingham S, Randall A, Sheardown SA (2000) Vanilloid receptor-1 is essential for inflammatory thermal hyperalgesia. Nature 405:183-187

Dhaka A, Murray AN, Mathur J, Earley TJ, Petrus MJ, Patapoutian A (2007) TRPM8 is required for cold sensation in mice. Neuron 54:371-378

Drew LJ, Rohrer DK, Price MP, Blaver KE, Cockayne DA, Cesare P, Wood JN (2004) Acid-sensing ion channels ASIC2 and ASIC3 do not contribute to mechanically activated currents in mammalian sensory neurones. J Physiol 556:691-710

Ford T, Beitinger TL (2005) Temperature tolerance in the goldfish Carassius auratus. J Therm Biol 30:147-152

Frings S (2009) Primary processes in sensory cells: current advances. J Comp Physiol A Neuroethol Sens Neural Behav Physiol 195:1-19

Gavva NR, Klionsky L, Qu Y, Shi L, Tamir R, Edenson S, Zhang TJ, Viswanadhan VN, Toth A, Pearce LV, Vanderah TW, Porreca F, Blumberg PM, Lile J, Sun Y, Wild K, Louis JC, Treanor JJ (2004) Molecular determinants of vanilloid sensitivity in TRPV1. J Biol Chem 279:20283-20295

Gentle MJ (1989) Cutaneous sensory afferents recorded from the nervus intramandibularis of Gallus gallus var domesticus. J Comp Physiol A 164:763-774

Gentle MJ, Tilston V, McKeegan DE (2001) Mechanothermal nociceptors in the scaly skin of the chicken leg. Neuroscience 106:643-652

Getting PA (1976) Afferent neurons mediating escape swimming of the marine mollusc, Tritonia. J Comp Physiol A 110:271-286

Goadby P (1959) Sharks and other predatory fish of Australia. Jacaranda Press, Brisbane

Gold MS, Reichling DB, Shuster MJ, Levine JD (1996) Hyperalgesic agents increase a tetrodotoxin-resistant $\mathrm{Na}^{+}$current in nociceptors. Proc Natl Acad Sci USA 93:1108-1112

Goodman MB (2006) Mechanosensation. WormBook:1-14

Goodman MB, Ernstrom GG, Chelur DS, O'Hagan R, Yao CA, Chalfie M (2002) MEC-2 regulates C. elegans $\mathrm{DEG} / \mathrm{ENaC}$ channels needed for mechanosensation. Nature 415:1039-1042

Grant AD, Cottrell GS, Amadesi S, Trevisani M, Nicoletti P, Materazzi S, Altier C, Cenac N, Zamponi GW, Bautista-Cruz F, Lopez CB, Joseph EK, Levine JD, Liedtke W, Vanner S, Vergnolle N, Geppetti P, Bunnett NW (2007) Protease-activated receptor 2 sensitizes the transient receptor potential vanilloid 4 ion channel to cause mechanical hyperalgesia in mice. J Physiol 578:715-733

Grimmelikhuijzen CJ, Westfall JA (1995) The nervous system of cnidarians. EXS 72:7-24

Hadrys T, DeSalle R, Sagasser S, Fischer N, Schierwater B (2005) The Trichoplax $\mathrm{PaxB}$ gene: a putative Proto-PaxA/B/C gene predating the origin of nerve and sensory cells. Mol Biol Evol 22:15691578

Hamamoto DT, Simone DA (2003) Characterization of cutaneous primary afferent fibers excited by acetic acid in a model of nociception in frogs. J Neurophysiol 90:566-577

Hamamoto DT, Forkey MW, Davis WL, Kajander KC, Simone DA (2000) The role of $\mathrm{pH}$ and osmolarity in evoking the acetic acidinduced wiping response in a model of nociception in frogs. Brain Res 862:217-229

Handwerker HO, Kilo S, Reeh PW (1991) Unresponsive afferent nerve fibres in the sural nerve of the rat. J Physiol 435:229-242

Hesselager M, Timmermann DB, Ahring PK (2004) pH Dependency and desensitization kinetics of heterologously expressed combinations of acid-sensing ion channel subunits. J Biol Chem 279:11006-11015

Hilliard MA, Bargmann CI, Bazzicalupo P (2002) C. elegans responds to chemical repellents by integrating sensory inputs from the head and the tail. Curr Biol 12:730-734
Hobert O (2005) Specification of the nervous system. WormBook:1-19

Hu J, Milenkovic N, Lewin GR (2006) The high threshold mechanotransducer: a status report. Pain 120:3-7

Huang M, Gu G, Ferguson EL, Chalfie M (1995) A stomatin-like protein necessary for mechanosensation in C. elegans. Nature 378:292-295

Huang J, Zhang X, McNaughton PA (2006a) Inflammatory pain: the cellular basis of heat hyperalgesia. Curr Neuropharmacol 4:197206

Huang J, Zhang X, McNaughton PA (2006b) Modulation of temperature-sensitive TRP channels. Semin Cell Dev Biol 17:638-645

Hwang RY, Zhong L, Xu Y, Johnson T, Zhang F, Deisseroth K, Tracey WD (2007) Nociceptive neurons protect Drosophila larvae from parasitoid wasps. Curr Biol 17:2105-2116

Iggo A (1960) Cutaneous mechanoreceptors with afferent C fibres. J Physiol 152:337-353

Illich PA, Walters ET (1997) Mechanosensory neurons innervating Aplysia siphon encode noxious stimuli and display nociceptive sensitization. J Neurosci 17:459-469

Jones NG, Slater R, Cadiou H, McNaughton P, McMahon SB (2004) Acid-induced pain and its modulation in humans. J Neurosci 24:10974-10979

Jones RC 3rd, Xu L, Gebhart GF (2005) The mechanosensitivity of mouse colon afferent fibers and their sensitization by inflammatory mediators require transient receptor potential vanilloid 1 and acid-sensing ion channel 3. J Neurosci 25:10981-10989

Jordt SE, Julius D (2002) Molecular basis for species-specific sensitivity to "hot" chili peppers. Cell 108:421-430

Jordt SE, Bautista DM, Chuang HH, McKemy DD, Zygmunt PM, Hogestatt ED, Meng ID, Julius D (2004) Mustard oils and cannabinoids excite sensory nerve fibres through the TRP channel ANKTM1. Nature 427:260-265

Kaplan JM, Horvitz HR (1993) A dual mechanosensory and chemosensory neuron in Caenorhabditis elegans. Proc Natl Acad Sci USA 90:2227-2231

Karashima Y, Talavera K, Everaerts W, Janssens A, Kwan KY, Vennekens R, Nilius B, Voets T (2009) TRPA1 acts as a cold sensor in vitro and in vivo. Proc Natl Acad Sci USA 106:1273-1278

Kavaliers M (1988) Evolutionary and comparative aspects of nociception. Brain Res Bull 21:923-931

Kavaliers M, Hirst M, Teskey GC (1983) A functional role for an opiate system in snail thermal behavior. Science 220:99-101

Kenton B, Kruger L, Woo M (1971) Two classes of slowly adapting mechanoreceptor fibres in reptile cutaneous nerve. J Physiol 212:21-44

Kleinhaus AL, Prichard JW (1983) Differential action of tetrodotoxin on identified leech neurons. Comp Biochem Physiol C 74:211218

Koerber HR, Druzinsky RE, Mendell LM (1988) Properties of somata of spinal dorsal root ganglion cells differ according to peripheral receptor innervated. J Neurophysiol 60:1584-1596

Koltzenburg M, Lewin GR (1997) Receptive properties of embryonic chick sensory neurons innervating skin. J Neurophysiol 78:2560-2568

Koltzenburg M, Stucky CL, Lewin GR (1997) Receptive properties of mouse sensory neurons innervating hairy skin. J Neurophysiol 78:1841-1850

Koopowitz H (1973) Primitive nervous systems. A sensory nerve-net in the polcald flatworm Notoplana acticola. Biol Bull 145:352359

Kress M, Koltzenburg M, Reeh PW, Handwerker HO (1992) Responsiveness and functional attributes of electrically localized terminals of cutaneous $\mathrm{C}$-fibers in vivo and in vitro. $\mathrm{J}$ Neurophysiol 68:581-595 
Kruger L, Perl ER, Sedivec MJ (1981) Fine structure of myelinated mechanical nociceptor endings in cat hairy skin. J Comp Neurol 198:137-154

Kwan KY, Corey DP (2009) Burning cold: involvement of TRPA1 in noxious cold sensation. J Gen Physiol 133:251-256

Kwan KY, Allchorne AJ, Vollrath MA, Christensen AP, Zhang DS, Woolf CJ, Corey DP (2006) TRPA1 contributes to cold, mechanical, and chemical nociception but is not essential for hair-cell transduction. Neuron 50:277-289

Kwan KY, Glazer JM, Corey DP, Rice FL, Stucky CL (2009) TRPA1 modulates mechanotransduction in cutaneous sensory neurons. J Neurosci 29:4808-4819

Lawson SN (2002) Phenotype and function of somatic primary afferent nociceptive neurones with C-, Adelta- or Aalpha/beta-fibres. Exp Physiol 87:239-244

Lawson JJ, McIlwrath SL, Woodbury CJ, Davis BM, Koerber HR (2008) TRPV1 unlike TRPV2 is restricted to a subset of mechanically insensitive cutaneous nociceptors responding to heat. J Pain 9:298-308

Lechner SG, Lewin GR (2009) Peripheral sensitisation of nociceptors via G-protein-dependent potentiation of mechanotransduction currents. J Physiol 587:3493-3503

Lechner SG, Frenzel H, Wang R, Lewin GR (2009) Developmental waves of mechanosensitivity acquisition in sensory neuron subtypes during embryonic development. EMBO J 28:1479-1491

Leonard RB (1985) Primary afferent receptive field properties and neurotransmitter candidates in a vertebrate lacking unmyelinated fibers. Prog Clin Res 176:135-145

Levina N, Totemeyer S, Stokes NR, Louis P, Jones MA, Booth IR (1999) Protection of Escherichia coli cells against extreme turgor by activation of $\mathrm{MscS}$ and $\mathrm{MscL}$ mechanosensitive channels: identification of genes required for MscS activity. EMBO J 18:1730-1737

Lewin GR, Mendell LM (1994) Regulation of cutaneous C-fiber heat nociceptors by nerve growth factor in the developing rat. J Neurophysiol 71:941-949

Lewin GR, Moshourab R (2004) Mechanosensation and pain. J Neurobiol 61:30-44

Lewin GR, Lu Y, Park TJ (2004) A plethora of painful molecules. Curr Opin Neurobiol 14:443-449

Liang YF, Terashima S (1993) Physiological properties and morphological characteristics of cutaneous and mucosal mechanical nociceptive neurons with A- 6 peripheral axons in the trigeminal ganglia of crotaline snakes. J Comp Neurol 328:88-102

Liang YF, Terashima S, Zhu AQ (1995) Distinct morphological characteristics of touch, temperature, and mechanical nociceptive neurons in the crotaline trigeminal ganglia. J Comp Neurol 360:621-633

Lingueglia E, de Weille JR, Bassilana F, Heurteaux C, Sakai H, Waldmann R, Lazdunski M (1997) A modulatory subunit of acid sensing ion channels in brain and dorsal root ganglion cells. J Biol Chem 272:29778-29783

Lockery SR, Goodman MB (2009) The quest for action potentials in C. elegans neurons hits a plateau. Nat Neurosci 12:377-378

Lockery SR, Goodman MB, Faumont S (2009) First report of action potentials in a C.elegans neuron is premature. Nat Neurosci 12:365-366

Loken LS, Wessberg J, Morrison I, McGlone F, Olausson H (2009) Coding of pleasant touch by unmyelinated afferents in humans. Nat Neurosci 12:547-548

Lynn B (1994) The fibre composition of cutaneous nerves and the classification and response properties of cutaneous afferents, with particular reference to nociception. Pain Rev 1:172-183

Ma Q, Fode C, Guillemot F, Anderson DJ (1999) Neurogenin1 and neurogenin2 control two distinct waves of neurogenesis in developing dorsal root ganglia. Genes Dev 13:1717-1728
Madrid R, de la Pena E, Donovan-Rodriguez T, Belmonte C, Viana F (2009) Variable threshold of trigeminal cold-thermosensitive neurons is determined by a balance between TRPM8 and Kv1 potassium channels. J Neurosci 29:3120-3131

Malin SA, Davis BM, Koerber HR, Reynolds IJ, Albers KM, Molliver DC (2008) Thermal nociception and TRPV1 function are attenuated in mice lacking the nucleotide receptor P2Y2. Pain 138:484 496

Martin AR, Wickelgren WO (1971) Sensory cells in the spinal cord of the sea lamprey. J Physiol 212:65-83

Martinez-Salgado C, Benckendorff AG, Chiang LY, Wang R, Milenkovic N, Wetzel C, Hu J, Stucky CL, Parra MG, Mohandas N, Lewin GR (2007) Stomatin and sensory neuron mechanotransduction. J Neurophysiol 98(6):3802-3808

Matthews G, Wickelgren WO (1978) Trigeminal sensory neurons of the sea lamprey. J Comp Physiol A 123:329-333

McCarter GC, Reichling DB, Levine JD (1999) Mechanical transduction by rat dorsal root ganglion neurons in vitro. Neurosci Lett 273:179-182

McKemy DD, Neuhausser WM, Julius D (2002) Identification of a cold receptor reveals a general role for TRP channels in thermosensation. Nature 416:52-58

Mellem JE, Brockie PJ, Madsen DM, Maricq AV (2008) Action potentials contribute to neuronal signaling in C. elegans. Nat Neurosci 11:865-867

Mellem JE, Brockie PJ, Madsen DM, Maricq AV (2009) Reply to "First report of action potentials in a C. elegans neuron is premature". Nat Neurosci 12:366

Mendell LM (1966) Physiological properties of unmyelinated fiber projection to the spinal cord. Exp Neurol 16:316-332

Meyer RA, Davis KD, Cohen RH, Treede RD, Campbell JN (1991) Mechanically insensitive afferents (MIAs) in cutaneous nerves of monkey. Brain Res 561:252-261

Milenkovic N, Frahm C, Gassmann M, Griffel C, Erdmann B, Birchmeier C, Lewin GR, Garratt AN (2007) Nociceptive tuning by stem cell factor/c-kit signaling. Neuron 56:893-906

Milenkovic N, Wetzel C, Moshourab R, Lewin GR (2008) Speed and temperature dependences of mechanotransduction in afferent fibers recorded from the mouse saphenous nerve. J Neurophysiol 100:2771-2783

Millan MJ (1999) The induction of pain: an integrative review. Prog Neurobiol 57:1-164

Mogil JS, Kest B, Sadowski B, Belknap JK (1996) Differential genetic mediation of sensitivity to morphine in genetic models of opiate antinociception: influence of nociceptive assay. J Pharmacol Exp Ther 276:532-544

Momin A, Wood JN (2008) Sensory neuron voltage-gated sodium channels as analgesic drug targets. Curr Opin Neurobiol 18:383-388

Momin A, Cadiou H, Mason A, McNaughton PA (2008) Role of the hyperpolarization-activated current $\mathrm{Ih}$ in somatosensory neurons. J Physiol 586:5911-5929

Montell C, Rubin GM (1989) Molecular characterization of the Drosophila trp locus: a putative integral membrane protein required for phototransduction. Neuron 2:1313-1323

Namer B, Handwerker HO (2009) Translational nociceptor research as guide to human pain perceptions and pathophysiology. Exp Brain Res 196:163-172

Near TJ (2009) Conflict and resolution between phylogenies inferred from molecular and phenotypic data sets for hagfish, lampreys, and gnathostomes. J Exp Zool B Mol Dev Evol. doi:10.1002/ jez.b.21293

Necker R, Reiner B (1980) Temperature-sensitive mechanoreceptors, thermoreceptors and heat nociceptors in the feathered skin of pigeons. J Comp Physiol A 135:201-207

Nicholls JG, Baylor DA (1968) Specific modalities and receptive fields of sensory neurons in CNS of the leech. J Neurophysiol 31:740-756 
Nordgreen J, Garner JP, Janczak AM, Ranheim B, Muir WM, Horsberg TE (2009) Thermonociception in fish: effects of two different doses of morphine on thermal threshold and post-test behaviour in goldfish (Carassius auratus). Appl Ani Behav Sci 119:101-107

O'Hagan R, Chalfie M, Goodman MB (2005) The MEC-4 DEG/ENaC channel of Caenorhabditis elegans touch receptor neurons transduces mechanical signals. Nat Neurosci 8:43-50

Page AJ, Brierley SM, Martin CM, Martinez-Salgado C, Wemmie JA, Brennan TJ, Symonds E, Omari T, Lewin GR, Welsh MJ, Blackshaw LA (2004) The ion channel ASIC1 contributes to visceral but not cutaneous mechanoreceptor function. Gastroenterology 127:1739-1747

Page AJ, Brierley SM, Martin CM, Price MP, Symonds E, Butler R, Wemmie JA, Blackshaw LA (2005) Different contributions of ASIC channels 1a, 2, and 3 in gastrointestinal mechanosensory function. Gut 54:1408-1415

Park TJ, Lu Y, Juttner R, Smith ES, Hu J, Brand A, Wetzel C, Milenkovic N, Erdmann B, Heppenstall PA, Laurito CE, Wilson SP, Lewin GR (2008) Selective inflammatory pain insensitivity in the African naked mole-rat (Heterocephalus glaber). PLoS Biol 6:e13

Passano LM, Pantin CFA (1955) Mechanical stimulation in the seaanemone Calliactis parasitica. Proc R Soc Lond B 143:226-238

Pastor J, Soria B, Belmonte C (1996) Properties of the nociceptive neurons of the leech segmental ganglion. J Neurophysiol 75:22682279

Pezalla PD (1983) Morphine-induced analgesia and explosive motor behavior in an amphibian. Brain Res 273:297-305

Price MP, Lewin GR, McIlwrath SL, Cheng C, Xie J, Heppenstall PA, Stucky CL, Mannsfeldt AG, Brennan TJ, Drummond HA, Qiao J, Benson CJ, Tarr DE, Hrstka RF, Yang B, Williamson RA, Welsh MJ (2000) The mammalian sodium channel BNC1 is required for normal touch sensation. Nature 407:1007-1011

Price MP, McIlwrath SL, Xie J, Cheng C, Qiao J, Tarr DE, Sluka KA, Brennan TJ, Lewin GR, Welsh MJ (2001) The DRASIC cation channel contributes to the detection of cutaneous touch and acid stimuli in mice. Neuron 32:1071-1083

Reeh PW (1986) Sensory receptors in mammalian skin in an in vitro preparation. Neurosci Lett 66:141-146

Reid G (2005) ThermoTRP channels and cold sensing: what are they really up to? Pflugers Arch 451:250-263

Renganathan M, Cummins TR, Waxman SG (2001) Contribution of $\mathrm{Na}(\mathrm{v}) 1.8$ sodium channels to action potential electrogenesis in DRG neurons. J Neurophysiol 86:629-640

Richards GS, Simionato E, Perron M, Adamska M, Vervoort M, Degnan BM (2008) Sponge genes provide new insight into the evolutionary origin of the neurogenic circuit. Curr Biol 18:1156-1161

Rose JD (2003) A critique of the paper: "Do fish have nociceptors: Evidence for the evolution of a vertebrate sensory system'. In: Erickson HE (ed) Information resources on fish welfare 19702003. U.S. Department of Agriculture, Beltsville, pp 49-51

Ross DM (1968) Detachment of sea anemones by commensal hermit crabs and by mechanical and electrical stimuli. Nature 217:380 381

Rush AM, Cummins TR, Waxman SG (2007) Multiple sodium channels and their roles in electrogenesis within dorsal root ganglion neurons. J Physiol 579:1-14

Sakharov D, Nezlin L, Moroz L, Elofsson R (1993) Patterns of enkephalin immunolabeling in the pulmonate snail Cepaea nemoralis and related molluscs. Brain Res 620:114-121

Sambongi Y, Takeda K, Wakabayashi T, Ueda I, Wada Y, Futai M (2000) Caenorhabditis elegans senses protons through amphid chemosensory neurons: proton signals elicit avoidance behavior. Neuroreport 11:2229-2232

Schafer WR (2005) Egg-laying. WormBook:1-7
Schlue WR (1976) Current excitation threshold in sensory neurons of leech central nervous system. J Neurophysiol 39:1176-1183

Schmidt R, Schmelz M, Forster C, Ringkamp M, Torebjork E, Handwerker H (1995) Novel classes of responsive and unresponsive C nociceptors in human skin. J Neurosci 15:333-341

Sherrington CS (1903) Qualitative difference of spinal reflex corresponding with qualitative difference of cutaneous stimulus. J Physiol 30:39-46

Shu X, Mendell LM (1999) Nerve growth factor acutely sensitizes the response of adult rat sensory neurons to capsaicin. Neurosci Lett 274:159-162

Smith ES, Cadiou H, McNaughton PA (2007a) Arachidonic acid potentiates acid-sensing ion channels in rat sensory neurons by a direct action. Neuroscience 145:686-698

Smith ES, Zhang X, Cadiou H, McNaughton PA (2007b) Proton binding sites involved in the activation of acid-sensing ion channel ASIC2a. Neurosci Lett 426:12-17

Sneddon LU (2002) Anatomical and electrophysiological analysis of the trigeminal nerve in a teleost fish, Oncorhynchus mykiss. Neurosci Lett 319:167-171

Sneddon LU (2003a) The evidence for pain in fish: the use of morphine as an analgesic. Appl Ani Behav Sci 83:153-162

Sneddon LU (2003b) Trigeminal somatosensory innervation of the head of a teleost fish with particular reference to nociception. Brain Res 972:44-52

Sneddon LU (2004) Evolution of nociception in vertebrates: comparative analysis of lower vertebrates. Brain Res Brain Res Rev 46:123-130

Sneddon LU, Braithwaite VA, Gentle MJ (2003) Do fishes have nociceptors? Evidence for the evolution of a vertebrate sensory system. Proc Biol Sci 270:1115-1121

Snow PJ, Plenderleith MB, Wright LL (1993) Quantitative study of primary sensory neurone populations of three species of elasmobranch fish. J Comp Neurol 334:97-103

Sokabe T, Tsujiuchi S, Kadowaki T, Tominaga M (2008) Drosophila painless is a $\mathrm{Ca} 2+-$ requiring channel activated by noxious heat. J Neurosci 28:9929-9938

Srinivasan J, Durak O, Sternberg PW (2008) Evolution of a polymodal sensory response network. BMC Biol 6:52

Srivastava M, Begovic E, Chapman J, Putnam NH, Hellsten U, Kawashima T, Kuo A, Mitros T, Salamov A, Carpenter ML, Signorovitch AY, Moreno MA, Kamm K, Grimwood J, Schmutz J, Shapiro H, Grigoriev IV, Buss LW, Schierwater B, Dellaporta SL, Rokhsar DS (2008) The Trichoplax genome and the nature of placozoans. Nature 454:955-960

Steen KH, Reeh PW, Anton F, Handwerker HO (1992) Protons selectively induce lasting excitation and sensitization to mechanical stimulation of nociceptors in rat skin, in vitro. J Neurosci 12:86-95

Story GM, Peier AM, Reeve AJ, Eid SR, Mosbacher J, Hricik TR, Earley TJ, Hergarden AC, Andersson DA, Hwang SW, McIntyre P, Jegla T, Bevan S, Patapoutian A (2003) ANKTM1, a TRP-like channel expressed in nociceptive neurons, is activated by cold temperatures. Cell 112:819-829

Sukharev SI, Blount P, Martinac B, Blattner FR, Kung C (1994) A large-conductance mechanosensitive channel in E. coli encoded by mscL alone. Nature 368:265-268

Thomas AW, Kavaliers M, Prato FS, Ossenkopp KP (1997) Pulsed magnetic field induced "analgesia" in the land snail, Cepaea nemoralis, and the effects of mu, delta, and kappa opioid receptor agonists/antagonists. Peptides 18:703-709

Tobin DM, Bargmann CI (2004) Invertebrate nociception: behaviors, neurons and molecules. J Neurobiol 61:161-174

Tominaga M, Caterina MJ, Malmberg AB, Rosen TA, Gilbert H, Skinner K, Raumann BE, Basbaum AI, Julius D (1998) The cloned capsaicin receptor integrates multiple pain-producing stimuli. Neuron 21:531-543 
Tracey I (2005) Nociceptive processing in the human brain. Curr Opin Neurobiol 15:478-487

Tracey WD Jr, Wilson RI, Laurent G, Benzer S (2003) Painless, a Drosophila gene essential for nociception. Cell 113:261-273

Treede RD, Meyer RA, Raja SN, Campbell JN (1992) Peripheral and central mechanisms of cutaneous hyperalgesia. Prog Neurobiol 38:397-421

Troemel ER, Chou JH, Dwyer ND, Colbert HA, Bargmann CI (1995) Divergent seven transmembrane receptors are candidate chemosensory receptors in C. elegans. Cell 83:207-218

Ugawa S, Ueda T, Ishida Y, Nishigaki M, Shibata Y, Shimada S (2002) Amiloride-blockable acid-sensing ion channels are leading acid sensors expressed in human nociceptors. J Clin Invest 110:1185-1190

Vallbo AB, Hagbarth KE (1968) Activity from skin mechanoreceptors recorded percutaneously in awake human subjects. Exp Neurol 21:270-289

Walters ET (1996) Comparative and evolutionary aspects of nociceptor function. In: Belmonte C, Cervero F (eds) Neurobiology of nociceptors. Oxford University Press, Oxford, pp 92-114

Walters ET, Byrne JH, Carew TJ, Kandel ER (1983) Mechanoafferent neurons innervating tail of Aplysia. I. Response properties and synaptic connections. J Neurophysiol 50:1522-1542

Weidner C, Schmelz M, Schmidt R, Hansson B, Handwerker HO, Torebjork HE (1999) Functional attributes discriminating mechano-insensitive and mechano-responsive $\mathrm{C}$ nociceptors in human skin. J Neurosci 19:10184-10190

Wenk HN, McCleskey EW (2007) A novel mouse skeletal musclenerve preparation and in vitro model of ischemia. J Neurosci Methods 159:244-251

Weston KM, Foster W, Weston AH (1984) Application of irritant chemicals selectively to the skin of the leech ganglion/body wall preparation. J Pharmacol Methods 12:285-297
Wetzel C, Hu J, Riethmacher D, Benckendorff A, Harder L, Eilers A, Moshourab R, Kozlenkov A, Labuz D, Caspani O, Erdmann B, Machelska H, Heppenstall PA, Lewin GR (2007) A stomatindomain protein essential for touch sensation in the mouse. Nature 445:206-209

Whitear M (1971) The free nerve endings in fish epidermis. J Zool Lond 163:231-236

Willenbring S, Stevens CW (1996) Thermal, mechanical and chemical peripheral sensation in amphibians: opioid and adrenergic effects. Life Sci 58:125-133

Wittenburg N, Baumeister R (1999) Thermal avoidance in Caenorhabditis elegans: an approach to the study of nociception. Proc Natl Acad Sci USA 96:10477-10482

Wood JN, Winter J, James IF, Rang HP, Yeats J, Bevan S (1988) Capsaicin-induced ion fluxes in dorsal root ganglion cells in culture. J Neurosci 8:3208-3220

Woodbury CJ, Zwick M, Wang S, Lawson JJ, Caterina MJ, Koltzenburg M, Albers KM, Koerber HR, Davis BM (2004) Nociceptors lacking TRPV1 and TRPV2 have normal heat responses. J Neurosci 24:6410-6415

Woolf CJ, Ma Q (2007) Nociceptors-noxious stimulus detectors. Neuron 55:353-364

Woolf CJ, Walters ET (1991) Common patterns of plasticity contributing to nociceptive sensitization in mammals and Aplysia. Trends Neurosci 14:74-78

Xu SY, Cang CL, Liu XF, Peng YQ, Ye YZ, Zhao ZQ, Guo AK (2006) Thermal nociception in adult Drosophila: behavioral characterization and the role of the painless gene. Genes Brain Behav 5:602-613

Zurborg S, Yurgionas B, Jira JA, Caspani O, Heppenstall PA (2007) Direct activation of the ion channel TRPA1 by $\mathrm{Ca}^{2+}$. Nat Neurosci $10: 277-279$ 